\title{
Green Supply Chain Practices Evaluation in the Mining Industry using a Joint Rough Sets and Fuzzy TOPSIS Methodology
}

\author{
Simonov Kusi-Sarpong \\ School of Management Science and Engineering \\ Dalian University of Technology \\ No .2 Linggong Road, Ganjingzi District \\ Dalian Liaoning Province (116023) P.R of China \\ E-mail: simonov2002@yahoo.com
}

\section{Chunguang Bai}

School of Management Science and Engineering

Dongbei University of Finance \& Economics

Jianshan Street 217

Dalian, 116025, P.R.China

Tel: (86411) 8690-4888

Fax: (86411) 87403733

E-mail: chunguang.bai@,dufe.edu.cn

\author{
Joseph Sarkis \\ School of Business \\ Worcester Polytechnic Institute \\ 100 Institute Road \\ Worcester, MA 01609-2280, USA \\ Tel: (508) 831-4831 \\ E-mail: jsarkis@,wpi.edu
}

\author{
Xuping Wang \\ School of Management Science and Engineering \\ Dalian University of Technology \\ No .2 Linggong Road, Ganjingzi District \\ Dalian Liaoning Province (116023) P.R of China \\ School of Business \\ Dalian University of Technology \\ Panjin Liaoning Province (124221) P.R of China \\ E-mail: wxp@dlut.edu.cn
}




\begin{abstract}
Environmental issues from the extractive industries and especially mining are prevalent and maleficent. An effective way to manage these pernicious environmental problems is through organizational practices that include the broader supply chain. Green supply chain practices and their role in mining industry strategy and operations have not been comprehensively addressed. To address this gap in the literature, and building upon literature in general green supply chain management and environmental decision tools, we introduce a comprehensive framework for green supply chain practices in the mining industry. The framework is categorized into six areas of practice, with detailed practices described and summarized. The green supply chain practices framework is useful for practical managerial decision making purposes such as programmatic evaluation. The framework may also be useful as a theoretical construct for empirical research on green supply chain practices in the mining industry. To exemplify the practical utility of the framework we introduce a multiple criteria evaluation of green supply programs using a novel multiple criteria approach that integrates rough set theory elements and fuzzy TOPSIS. Using illustrative data we provide an example of how the methodology can be used with the green supply chain practices framework for the mining industry. This paper sets the foundation for significant future research in green supply chain practices in the mining industry.
\end{abstract}

\title{
Keywords: Green Supply Chain Practices, Program Evaluation, Rough Set Theory, Mining Industry, Information Theory
}

\section{INTRODUCTION}


Mining operations and supply chain activities are mired with serious socio-environmental consequences, and underlying economic implications (Hilson and Nayee, 2002; Poulton et al., 2013). These mining activities have brought about massive environmental degradation and natural resources depletion, threatening future opportunities for sustainable industrial development and economic growth. Mining companies generate a wide range of environmental impacts from their mining operations. Mining activities such as exploration, ore mining, and maintenance activities all contribute to serious environmental problems such as soil erosion, tailings contamination, oil spills, cyanide release, dust or noise nuisance, and acid mine drainage (Hilson and Nayee, 2002; Muduli et al., 2013). The design and extraction of natural resources (ore) through mining activities using high toxic reagents can generate carbon dioxide (CO2) emissions and pollutants; deplete water and land resources, and produce waste products disposed into the environment. During exploration stages, vegetation is removed to enable the creation of access roads to the mineralized zone for drilling activities. These exploration and mining activities result in serious soil erosion, destruction of habitat, and soil and water contamination from hazardous materials and oil spills. Additionally, during the mines mineral leaching and extraction stages, cyanide, an extremely toxic chemical is used in the process and becomes part of the tailings (waste) which are ultimately disposed into a tailings dam. This type of environmental damage may result in the release of cyanide from the tailing dam to the water bodies causing intoxication of wildlife drawn to water.

As a result of these and additional environmental issues facing mining operations, mining companies are mired with numerous environmental challenges which require them to carefully address regulatory concerns while meeting diverse stakeholder groups' demands (Hilson and Nayee, 2002; Mzembe and Meaton, 2013; Dobele et al., 2014). Therefore, mining companies are seeking to reduce the impact of their operations on the environment. Environmental concerns in mining 
industries have grown to include extended producer responsibility to help address their environmental impacts (Lenzen et al., 2007).

The extended producer responsibilities are not just for products but also for materials and byproducts such as those in extractive industries. Thus, concerns upstream and downstream in the mining supply chain, in addition to operations within a focal mining organization, all influence the supply chain. In this paper our objective is to introduce general factors and practices that may be elements of green supply chain management (GSCM) programs, with an especial focus on the mining industry. We also seek to introduce and evaluate novel multiple-criteria decision making (MCDM) tools to evaluate mining industry green supply chain practices.

To help accomplish these goals, we provide some contextual background to greening the supply chain in the mining industry with a review of various green supply chain practices that set the foundation for a general practices framework. Then, background on two core tools, rough set theory (entropy) valuations are used for weighting purposes to help in a multiple criteria evaluation of GSCM programs in a mining industry context. After introduction of the tools, an illustrative application and analysis is provided to exemplify the utility of this tool. Finally, we identify some of the major issues faced, implications, and future research directions associated with GSCM and decision making in the mining industry.

The contribution of this paper is multifold. First, we develop and introduce some green supply chain practices in a new typology and specifically for the mining industry. Second, we introduce a set of tools to help evaluate green supply chain practice programs in the mining industry. Third, this set of tools is novel for the first time integrating rough set (information theory) based weighting schemes within a TOPSIS decision framework. Overall, the development of factors, example illustration, and unique integration of tools, sets the foundation for further research in green supply chain sustainability of the mining industry and corporate sustainability practices in general. 


\section{BACKGROUND}

The mining industry has been an imperative economic activity for thousands of years. In fact, mining, such as gold mining has been a major industry in both developed and developing countries. But the economic benefits of mining of natural resources have been offset by its environmental degradation. In the mining industry efforts have been introduced to improve environmental performance. In managing this situation, tools to help mining company decision makers make sound decisions could be valuable. Overall, in greening and sustainability research model development, to help manage multiple criteria and tradeoffs associated with environmental, organizational, and economic performance have started to receive greater recognition amongst scholars (Bai et al., 2012; Brandenburg et al., 2014). In the GSCM literature, the use of quantitative models has only started to see increased evidence (Seuring, 2013; Brandenburg et al., 2014).

Sustainability decision tools that incorporate mining industry GSCM characteristics do not exist. This paper seeks to address this gap. Specifically this study focuses on the use of multiple-criteria decision making tools to help in GSCM programmatic development. Various environmentally supportive (green) supply chain practices can be administered through various programs that may be adopted by organizations. Sometimes these programs may be technological or organizational solutions, or a mixture. For example training programs may exist for a number of green supply practices, enterprise-wide information systems may support various green supply chain efforts, or suppliers and vendors may be selected that can support these practices. Choosing amongst these programs and how they influence practices is a critical issue faced by organizations. We shall utilize multiple criteria tools to help managers in a mining industry environment select amongst these programs.

The background section will begin with providing development of the major green supply chain practices faced by the mining industry. We then summarize these practices in a general green supply 
chain practices framework within the mining industry. We then introduce the methodologies in a second part of the background section.

\subsection{Factors (practices) of Green Supply Chain Management implementation in the Mining}

\section{Industry}

In spite of increased development and adoption of environmental management strategies among many mining companies in Ghana ${ }^{1}$ (and around the world), an increasing rise of environmental issues, especially from various supply chain activities, still exist. Factors hindering mining company environmental management improvements and capability building include the lack of approaches to identify, confirm, and validate, holistic mining industry GSCM practices.

This study identifies six (6) distinctive GSCM practices (factors) and sub-practices (factors) that include Green Information Technology and Systems (GITS), Strategic Supplier Partnership (SSP), Operations and Logistics Integration (OLI), Internal Environmental Management (IEM), EcoInnovation practices (ECO), and End-of-Life practices (EOL). To initially arrive at these practices and sub-practices for GSCM implementation in the mining industry, literature on GSCM, in general, and in the mining industry in particular was reviewed. Industrial experts, academicians, and government officials within Ghana were then consulted to help evaluate, confirm and focus the factors and sub-factors.

\footnotetext{
${ }^{1}$ Ghana was selected for this study because of its unique mining industry positioning (Boon and Ababio, 2009; Bloch \& Owusu, 2012). Mining accounts for 5\% of Ghana's GDP with minerals making up 37\% of total exports (Boon and Ababio, 2009). Gold makes up over $90 \%$ of the total mineral exports, thus, making gold the main focus of Ghana's mining and minerals development industry (Aryee, 2001). In Ghana, this sector have attracted about US $\$ 2$ billion of Foreign Direct Investment (FDI) in mineral exploration and mine development over the last decade which represent more than $56 \%$ of the total FDI in flows into the country (Awudi, 2002). It contributes roughly $12 \%$ of the government of Ghana's revenue, $7 \%$ of the total Ghana's corporate earnings and $41 \%$ of the total export earnings (Aryee \& Aboagye, 2008). Ghana currently has thirteen (13) large-scale mining companies producing gold, diamonds, bauxite and manganese, and, there are also over three hundred (300) registered small scale mining groups and ninety (90) mine support service companies (Mbendi, 1995-2013). It consistently ranks as one of Africa's largest producers of precious metals and minerals such as gold and diamonds.
} 
In the initial development methodology, the sub-factors were first grouped and listed under each of the major factors in a table with brief descriptions and explanations of the sub-factors provided. This list was first submitted to three respondents from the ministry of lands, forestry and mines and ministry of environment and science including two mining engineers with over 12 years of prior working experience in the Ghanaian mining industry as well as two respondents from academics, one with research interest in environmental science and the other with research interest in supply chain management for an initial review. This initial review resulted in a listing of 6 factors and 34 sub-factors.

The major factors and sub-factors were then distributed to four different industrial experts with a minimum of 10 years mining work experience from various mining companies in Ghana. The four industrial experts who were chosen for this exercise include; a Supply Manager with 18years mining work experience, an Environmental Manager with 10 years mining work experience, a Health, Safety and Environmental Manager with 22 years mining work experience, and a Mining Manager with 12 years work experience in the mining industry. These respondents were asked to share their opinions in what they perceive as either necessary, actual, or appropriate GSCM practices and sub-practices for the mining industry's GSCM implementation on a "Yes" or "No" basis. They were asked to add/suggest additional major factors and sub-factors they considered necessary but were not captured by the literature review. No additions or suggestions were made. The responses received were then tabulated and based on the number of respondent (4 in number), a threshold value of not less than 3"Yes" (75\%) per practice was agreed by the research team as the necessary number of affirmative votes for a sub-factor to be included in the final listing.

This methodology resulted in a final set of six major factors and thirty sub-factors. See Table 1 for the final listing. We now overview the remaining GSCM factors based on the literature review.

\subsubsection{Green Information Technology and Systems (GITS)}


Information Technology and Systems (ITS) are critical supply chain enablers in the mining industry (Gunasekaran and Ngai, 2004) with substantial benefits (Jenkin et al., 2011; Bai and Sarkis, 2013). Mining companies use traditional ITS' that enable them to integrate functional departments and suppliers (Gunasekaran and Ngai, 2004). For example, the use of enterprise resources planning (ERP) systems by mining companies makes it possible to easily track various transactions that take place across the various functional departments. Since mines operate almost continuously, all these IT systems, especially servers are required to be supporting this continuous operation. In mining companies, ITS' are seen as basic necessity for working and communicating, nearly every employee uses one kind of ITS' or the other, making ITS' operations alone contributes significantly to the environmental footprint (Faucheux and Nicolaï, 2011; Uddin and Rahman, 2012).

Although some harmful practices and effects on the environment from the use of ITS, 'Green' ITS can bring significant economic saving and minimize the environmental impact (Berl et al., 2010; Jenkin et al., 2011). With a large number of ITS uses in mining companies, mining companies need to switch from high energy consumption hardware systems to energy-efficient hardware systems. These energy-efficient hardware systems have the capacity to reduce data center (servers, network and storage devices) energy consumption through energy-saving devices in greening operations. Mining companies can also adopt and use collaborative group software and telepresence systems built with energy-saving devices which uses videoconferencing as an alternative to employees traveling (including meetings with suppliers).

These initiatives can also bring further energy reduction in transportation and promote the use of Green ITS-solutions based equipment. It further enables faster decision making and scale scarce resources (e.g. information is valuable in managing and reducing pipeline inventories (Christopher, 2005; 2010)) and waste. Another area that can increase the energy savings of the mining companies is server consolidation based on service virtualization. This divides computation resources and 
enables hardware sharing among various mines promoting energy efficiency. Server consolidation requires less hardware generally; hence cooling energy wasted is drastically reduced.

The mine SCMs encompass various functional departments and critical suppliers, hence, in managing these critical suppliers, ITS tools are used to collaboration the mines and these suppliers, increasing integration of the various value-added activities. This integration reduces logistics costs, through paperless transactions and reduced transportation carbon footprints (Allenby et al., 2001; Setterstrom, 2008; Watson et al., 2008; Chou and Chou, 2012).

\subsubsection{Strategic Supplier Partnership (SSP)}

Implementing GSCM practices in the mining industry requires partnership beyond the mining company's boundaries (Spekman and Carraway, 2006; Mentzer et al., 2000). Since mining companies are in a "primary industry", the finish products (for example gold, manganese, and other precious ores) are in the raw material stage. Demands for these products are nearly always high with significant customer competition for these materials. As a result, mining companies have a relatively lessened focus on downstream partnership practices (i.e. outbound logistics) since customers provide these services due to the competitive nature of this market. This lack of downstream focus is evident in green supply chain practices, for example customers have very little impact on environmental investment decisions (Vachon, 2007).

The cases of strategic partnerships in the mining industry are typically oriented toward the upstream portion of the supply chain. Mining companies form partnerships to strengthen their strategic and operational competences, develop mutual supply chain benefits, and improve total supply chain control (Tan et al, 2002; Vachon \& Klassen, 2006a; Vachon \& Klassen, 2006b; Vachon \& Mao, 2008; Gunasekaran et al., 2004).

\footnotetext{
2 Primary industries are involved with primary commodities by extracting natural resources or harvesting raw materials prior to processing.
} 
These strategic partnerships promote direct, long-term alliances, mutual planning, problem solving initiatives, shared environmental management knowledge, and joint development of environmental management solutions or programs to reduce or eliminate materials use in mining companies (Geffen and Rothenberg 2000, Gunasekaran et al, 2001, Rao 2002; Simpson et al., 2007).

These strategic partnerships further allow mining companies to collaborate with their critical suppliers and enable mines to communicate their sustainability goals to these suppliers and set environmental targets to monitor suppliers' environmental compliance status and practices in their operations. For example, the supplies of sodium cyanide procured by mines require strong adherence to the $\mathrm{ICMC}^{3}$ (if the mines signatory members) standards. Collaboration needs to occur between the mines and their suppliers to ensure best practices are applied to protect the environment.

\subsubsection{Operations and Logistics Integration (OLI)}

The activities related to logistics integration and production system operations may be considered the 'internal supply chain'. Logistics activities within mining companies involve organizing the delivery of raw materials, equipment and parts, and services to the mines. These activities include stocking supplies, ordering, transportation management ${ }^{4}$, inventory management, warehousing, and delivery to internal customers. The logistics and operations management processes may be integrated using ERP systems, and thus, may provide operations and logistics integration.

\footnotetext{
${ }^{3}$ The ICMC - "International Cyanide Management Code for the manufacture, transport, and use of cyanide in the production of gold" (Code) was developed by a multi-stakeholder Steering Committee under the guidance of the United Nations Environmental Program (UNEP) and the then- International Council on Metals and the Environment (ICME)" < http://www.cyanidecode.org/about-cyanide-code\#sthash.BiUnOFky.dpuf >(Assessed: 15 October, 2013). ICMC focuses on safe cyanide and cyanidation leach solution and mill tails management. Once a mining company that uses cyanide for gold recovery sign-on-to this code, they are require to be audited by an independent body to ascertain their level of compliance of the Code requirement. Once the requirements of the code are met by such mining company, they are certified and a unique trademark symbol can be utilized by the mines and subsequently, the audit report made public. ${ }^{4}$ To enable the flow of supplies from the suppliers to the mining companies, various long-term freight forwarders contracts for air- and ocean-freight at highly dominated purchased zones along in-country clearing agents and transporters have being signed between the mining companies and the freight agents and local clearing agents and transporters.
} 
Effective logistics and operations integration in mines require crossing organizational boundaries (Chen and Paulraj, 2004; Stock et al., 1999, 2000). The lack of mining organizations' external integration can have serious economic and environmental consequences. A typical example is the purchase of large quantities of raw materials and spares causing overstocks in warehouse inventory which may result in many types of material, space and energy waste.

Seamless integration with the mine's supply chain partners especially onto the mines ERP system offers real-time information sharing and visibility, promoting supplier's advance replenishment preparations, and a quick adjustment to sustain the mines operations when the mines observes changes/delays in their consignment (parts or materials) which improves plant availability, reduces persistence stock-out and overall cost of production. It further encourages electronic-ordering and tracking system as against paper-based ordering and tracking system. Integration helps promote green logistics activities such as green purchasing, vendor management, and collaboration, helping to minimize the impact of environmental issues associated with the flow of materials (example sodium cyanide which needs to meet UN codes) in the supply chain (Bowen et al., 2001; Min and Galle, 2001; Vachon and Klassen, 2008; Carter and Easton, 2011).

The core capabilities in mining companies are acquisition, maintenance and operating of mine machinery for the extraction and processing of mineralized ore body. Maintenance cost is estimated as $30 \%$ of the total operational cost of mining companies ${ }^{5}$. The use of mines-wide asset reliability approach of integrating all the key internal operational processes and activities will help to achieve operational reliability optimization leading to improve operational efficiencies and freeing up

5 Accenture (2011) "Global Operating Models for Mining Companies: Adding value beyond the individual assets", Mining Executive Series, pp 1-28 
additional capacity (efficient resources use), thus enabling mining companies to minimize cost, use resources efficiently and increase production throughput ${ }^{6}$.

\subsubsection{Internal Environmental Management (IEM)}

Addressing environmental concerns in mines requires total commitment and input from all members within the mining company. Internal environmental management (IEM) initiatives are required to be implemented company-wide to achieve this goal (Vachon \& Klassen, 2006a) of continuously integrating project processes from exploration to closure to achieve cleaner production (CP) (Hilson and Nayee, 2002).

Mining companies are required to have environmental pollution prevention plans as guides for employees. These plans and policies are meant to address environmental and safety concerns. Top management commitment for these plans and policies is required for IEM initiatives implementation. Allocating resources and funds to hire and maintain environmental experts (teams) for IEM is needed for continuous employee training on imperative environmental practices and management system procedures including auditing and reporting (Hilson and Nayee, 2002). IEM could incorporate Total Quality (environmental) Management (TQM) techniques to help suppliers reduce environmental pollution (Curkovic et al., 2000; Barla, 2007).

\subsubsection{Eco-Innovation Practices (ECO)}

Eco-innovation may be defined as the production, application or exploitation of a good, service, production process, organizational structure, or business method that is novel to the firm and results in reduction of environmental risk, pollution and burdens of resources use throughout their life cycle (Kemp \& Foxon, 2007). In the early stages of mining operations where minerals are processed into metals, by-products are produced and using innovations these byproducts can be converted to

${ }^{6} \mathrm{ibid}$ 
usable materials (Lutandula and Maloba, 2013). This eco-innovation may result in reduction of substantial amounts of mining waste.

Eco-innovative ideas are also enablers. For example, consider the use of environmentally friendly substitute reagents or chemicals with low-impact for high toxic reagent/chemicals (Azevedo et al., 2012). Within mining operations the use of 'ammoniacal thiosulfate" to process carbonaceous ores as an alternative to sodium cyanide for gold recovery is a substitution example. To reduce these environmental impacts and make more efficient use of natural resources, mining companies should integrate cleaner production system/cleaner extraction technologies. These eco-innovations improve the efficiency of previously used technologies and contribute to pollution reduction (Azevedo et al., 2012).

As another example, process metallurgy can be designed to maximize the recovery of minerals, decrease water use and impacts, improve mineral recovery efficiency and by-product values. Process plant redesign can also lead to effective use of resources and materials efficiency, greenhouse gas emissions and consumption of energy reduction, and improve minor elements control and toxic materials while reducing process waste generation (Carter and Easton, 2011; Azevedo et al., 2012).

\subsubsection{End-of-Life Practices (EOL)}

End-of-life solutions rely on external recycling and recovery of waste (Sarkis and Cordeiro, 2001; Wang and Gaustad, 2012) in response to decreased overall environmental impact and an economically beneficial alternative to ordering new products. Two kinds of end-of-life activities are involved in mining operation; reverse logistics for parts and components and recovery for chemical/reagents and re-mining of tailings.

\footnotetext{
7 The use of ammoniacal thiosulphate is a better alternative for gold extraction as it is a non-toxic and environmentally safe to use by the mining companies as compared to the high toxic sodium cyanide system of gold extraction (Rath et al., 2003).
} 
Reverse logistics (RL) in the supply chain results in products, parts, components, warrantedcomponents traveling in the opposite direction from consumers (downstream) to manufactures/suppliers (upstream) (Bell et al., 2013), for the purpose of defect reworking, product returns, refurbishment, rebuilding or repairing for reuse, reprocessing or controlled scrapping, old/obsolete items being replaced to reduce the environmental impact (Stock, 2001; Rogers and Tibben-Lembke, 2001; Sarkis, 2003). Mining companies use heavy mining machinery and equipment requiring the replacement of expensive worn-out parts or components after running for certain design hours or unforeseen breakdowns.

The use of RL initiatives by mining companies can generate substantial revenue from these older, used assets, selling them as used pumps and motors to secondhand markets. Some of this equipment may be put through component exchange programmes and sold back to the market. RL initiatives benefits may include revenue gain, secondary raw material gain by suppliers, avoidance of environmental issues related to improper disposal, raw material sustenance as a result of recycling products, freeing up or reduce storage space, and eliminating the risk and environment impacts involved in having them around (Cottrill, 1997; Atkinson, 2002).

Recovery activities (RA) decrease direct mining and mineral processing pollutants. RA may include cyanide, arsenic and sulphide solution recovery, carbon recovery and mining of tailings dams. During the adsorption stages of the extractive metallurgy, activated carbons are used for mineral recovery. These carbons must be effectively activated by "regeneration" for repeated use reducing fresh activated carbon purchase as input. Tailings contain fine-grained slurry mix with toxic substances such as sulphide, arsenic, and cyanide, which requires proper handling (Driussi and Jansz, 2006). Even though excessive waters are removed using screw classifiers and thickeners prior to discharging the tails into the dam, (Eswaraiah et al. 2012), yet tailings generally still remain 20\% saturated (Driussi and Jansz, 2006). As a result, the saturated solutions in the tailings are pump back 
to the process plant for reuse reducing the amount of fresh chemical to be purchase and use as input, and maximizing natural resources use by mining the remaining solid tails to recover the minerals concentrate that was previously not captured.

Table 1 provides a summary of GSCM practices and sub-factors identified through literature and confirmed through expert opinions from managers within the mining industry of Ghana.

\section{[Table 1 about here]}

\subsection{Overview of Environmental Multi-Criteria Decision-Making in the Mining Industry}

The past decade has seen an increasing volume of environmental management and supply chains decision modeling. Evaluating these green initiatives and programs are multidimensional issues. Thus, the need for and growth of MCDM tools to aid in these evaluations.

A number of efforts have occurred for general MCDM for environmental sciences decision making in general (Huang et al., 2011). Yet, within this context the mining industry has had very limited identified general application with only one article identified by Huang et al., 2011 (i.e. Soltanmohammadi, et al., 2009). The development of MCDM approaches to sustainable supply chains and green supplier selection has grown overall (Govindan et al., 2013). Researchers have utilized a variety of similar MCDM approaches such as combined fuzzy-ANP and FuzzyPROMETHEE (Tuzkaya et al., 2009); generalized Fuzzy TOPSIS (Awasthi et al., 2010; Awasthi et al, 2011) and fuzzy hierarchical TOPSIS (Wang and Chan, 2013) to investigate issues related to sustainable supply chain planning and supplier selection. Thus, the application of fuzzy TOPSIS is a good approach supported by the literature. But none of these and other MCDM approaches, until this special issue (e.g. Sivakumar et al., 2014 and Jia et al., 2014), have focused primarily on the mining industry. The inclusion of a filtering approach to help make TOPSIS and other MCDM techniques easier to apply and accept by management has not been considered. This is why we

introduce rough set as an approach to initially filter the factors to a more manageable size for 
environmental decision making. This filtering occurs with minimal loss of information from factor reduction.

We now provide background to the methodology introduced in this paper with respect to jointly linking up rough set theory with fuzzy TOPSIS.

\subsection{Methodological Background}

Now that we have a summary and hierarchical framework of GSCM practices applicable to the mining industry, these multiple practices can serve as a foundation for tools evaluating GSCM programs using multiple dimensional/criteria analysis. We now introduce two complementary tools both with capabilities for multiple factor and dimensional analysis that will be an illustrative application utilizing the GSCM practices facing the mining industry and introduced in the previous section. The two techniques are rough set theory (entropy analysis) and TOPSIS, in a fuzzy logic context.

\subsubsection{Rough Set Theory and Methodology}

Rough set theory (Pawlak, 1982) is a mathematical approach to evaluate process vagueness and ambiguous data. The method classifies objects into similarity clusters, called elementary sets, containing objects and evaluating these sets' indiscernibility. The objects in a cluster may have a relationship with the corresponding attributes. These similarity clusters are next employed to determine hidden patterns, as in data mining (Cheng et al., 2010; Shyng et al., 2010; Bai and Sarkis, 2010). Rough set theory has significant application in data mining approaches and applied to the management of a number of issues, including medical diagnosis, engineering reliability, expert systems, empirical study of insurance data, and business failure prediction (Shyng et al., 2010).

In rough set theory, the lower and upper approximation operators are based on an equivalence relation. Lower approximations describe the domain objects which definitely belong to the subset of interest. Upper approximations describe objects which may possibly belong to the subset of interest. 
The difference between the upper and the lower approximations constitutes a boundary region for the vague set. Hence, rough set theory expresses vagueness by employing a boundary region of a set. If the boundary region of a set is empty it means that the set is crisp, otherwise the set is rough (inexact). Some notation and definitions are now introduced to help set the stage for the multicriteria evaluation approach.

Definition1: Let $U$ be the universe and let $R$ be an equivalence relation on $U$. For any subset $X \in U$, the pair $T=(U, R)$ is called an approximation space.

The two subsets

$$
\begin{gathered}
\underline{R} X=\left\{x \in U \mid[x]_{R} \subseteq X\right\} \\
\bar{R} X=\left\{x \in U \mid[x]_{R} \cap X \neq \phi\right\}
\end{gathered}
$$

are called the R-lower (1) and $R$-upper (2) approximation of $X$, respectively.

$$
B N_{R}(X)=\bar{R} X-\underline{R} X
$$

Thus the R-boundary region of $X$ is represented by expression (3). If $B N_{R}(X)=0$, then we have a crisp set, a $B N_{R}(X)>0$ provides us with a rough set for our evaluation.

\subsubsection{TOPSIS}

TOPSIS (technique for order preference by similarity to an ideal solution) (Hwang and Yoon 1981) is a multiple criteria evaluation approach used to rank alternatives based on the shortest distance from the ideal solution and the furthest distance from the negative-ideal (nadir) solution. This method has been widely applied in the literature (Chen and Tzeng, 2004; Opricovica and Tzeng, 2004; Krohling and Campanharo, 2011; Bai and Sarkis, 2013). 
Definition 2: Let $S=(U, C, V, f)$ be an "information system" where $U$ is the universe, and $C$ is decision attribute sets for $U ; V=\bigcup_{c \in C} V_{c}$ indicates the factor range of factor $c, f: U \times C \rightarrow V$ is an information function, that is for $\forall x \in U$ if $c \in C$ then $f(x, c) \in V_{c}$.

The TOPSIS can be expressed the following steps:

(1) Determine the ideal and nadir solution.

$$
\begin{aligned}
P^{+} & =\left\{v_{1}^{+}, \ldots, v_{m}^{+}\right\} \\
& =\left\{\left(\max _{i} v_{i j} \mid j \in I\right),\left(\min _{i} v_{i j} \mid j \in J\right)\right\}, \\
P^{-} & =\left\{v_{1}^{-}, \ldots, v_{m}^{-}\right\} \\
& =\left\{\left(\min _{i} v_{i j} \mid j \in I\right),\left(\max _{i} v_{i j} \mid j \in J\right)\right\},
\end{aligned}
$$

where $I$ is associated with benefit criteria, and $J$ is associated with cost criteria.

(2) Calculate the separation measures, using the n-dimensional Euclidean distance. The separation of each alternative from the ideal solution is given as

$$
\mu_{i}^{+}=\sqrt{\sum_{j=1}^{m}\left(v_{i j}-v_{j}^{+}\right)^{2}, i}=1, \ldots, n .
$$

Similarly, the separation from the nadir solution is given as

$$
\mu_{i}^{-}=\sqrt{\sum_{j=1}^{m}\left(v_{i j}-v_{j}^{-}\right)^{2}}, i=1, \ldots, n .
$$

(3) Calculate the relative closeness to the ideal solution. The relative closeness of the alternative $P_{i}$ with respect to $P^{+}$is defined as

$$
T_{i}=\frac{\mu_{i}^{-}}{\mu_{i}^{+}+\mu_{i}^{-}}
$$


(4) Rank the preference order. The larger the value of $T_{i}$, the better the alternative $P_{i}$. The best alternative is the one with the greatest relative closeness to the ideal solution. Ranking for alternatives can be completed using a decreasing order value for $T_{i}$ (Opricovic and Tzeng, 2004).

\subsubsection{Triangular Fuzzy Numbers}

A fuzzy number is a convex fuzzy set, characterized by a given interval of real numbers, each with a grade of membership between 0 and 1 . The most commonly used fuzzy numbers are triangular fuzzy numbers. We now briefly introduce some basic definitions of the triangular fuzzy number function.

The triangular fuzzy number is based on a three-value judgment: the minimum possible value $x_{l}$, the most possible value $x_{m}$ and the maximum possible value $x_{u}$. Then the definition of a triangular fuzzy number is:

Definition 3: A triangular fuzzy number $\tilde{x}$ can be defined by a triplet $\left(x_{l}, x_{m}, x_{u}\right)$. The membership function is defined as Error! Reference source not found., depicted as in Figure 1.

$$
\mu_{\tilde{x}}(x)=\left\{\begin{array}{lc}
\left(x-x_{l}\right) /\left(x_{m}-x_{l}\right), & x_{l} \leq x<x_{m} \\
1, & x=x_{m} \\
\left(x_{u}-x\right) /\left(x_{u}-x_{m}\right), & x_{m}<x \leq x_{u} \\
0, & \text { otherwise }
\end{array}\right.
$$

where $x_{l} \leq x_{m} \leq x_{u}$, and $x_{l}$ and $x_{u}$ are the lower and upper bounds of $\tilde{x}$, respectively. $x_{m}$ is the mean of $\tilde{x}$.

\section{[Figure 1 about here]}

Obviously, if $x_{l}=x_{m}=x_{u}$ then the triangular fuzzy number $\tilde{x}$ is reduced to a real number. Thus, the triangular fuzzy number can be flexible to represent various semantics of uncertainty (Li, 2012). 
Definition 4: Let $\tilde{x}^{1}=\left(x_{l}^{1}, x_{m}^{1}, x_{u}^{1}\right)$ and $\tilde{x}^{2}=\left(x_{l}^{2}, x_{m}^{2}, x_{u}^{2}\right)$ be two triangular fuzzy numbers. The triangular fuzzy number mathematical operations are defined asError! Reference source not found.:

$$
\begin{gathered}
\tilde{x}^{1} \oplus \tilde{x}^{2}=\left(x_{l}^{1}+x_{l}^{2}, x_{m}^{1}+x_{m}^{2}, x_{u}^{1}+x_{u}^{2}\right) \\
\tilde{x}^{1} \otimes \tilde{x}^{2}=\left(x_{l}^{1} x_{l}^{2}, x_{m}^{1} x_{m}^{2}, x_{u}^{1} x_{u}^{2}\right) \\
\frac{\tilde{x}^{1}}{\tilde{x}^{2}}=\left(\frac{x_{l}^{1}}{x_{l}^{2}}, \frac{x_{m}^{1}}{x_{m}^{2}}, \frac{x_{u}^{1}}{x_{u}^{2}}\right) \\
\lambda \times \tilde{x}=\left(\lambda \times x_{l}, \lambda \times x_{m}, \lambda \times x_{u}\right), \lambda \geq 0, \lambda \in R
\end{gathered}
$$

Definition 5: Let the distance measure of two triangular fuzzy numbers be a Minkowski space distance which is represented in expression (11) Error! Reference source not found..

$$
L\left(\tilde{x}^{1}, \tilde{x}^{2}\right)=\left[1 / 3\left(\left(x_{l}^{1}-x_{l}^{2}\right)^{p}+\left(x_{m}^{1}-x_{m}^{2}\right)^{p}+\left(x_{u}^{1}-x_{u}^{2}\right)^{p}\right)\right]^{\frac{1}{p}}
$$

where $p$ is some exponential power, in our application $p=2$ (quadratic power).

\section{ILLUSTRATIVE EXAMPLE}

This hypothetical illustrative case will provide insights into application of rough set and fuzzyTOPSIS approaches for evaluation of programs based on GSCM practices. The technique proposed is composed of two stages and nine steps and are summarized in Table 2. The methodology to arrive at a final evaluation and/or ranking of GSCM practices is now presented. The first stage seeks to populate a decision table and determine the relative importance weights using rough set approaches.

\section{[Table 2 about here]}

Stage 1: Identify the Importance (Weight) of GSCM Practices by Rough Set

\section{Step 1: Populate the Original Decision System (Table)}


First, a decision table of GSCM practices needs to be formed. This decision table is defined by $T$ $=(U, C, D, V, f)$, where $U=\left\{P_{1}, P_{2}, \ldots, P_{\mathrm{m}}\right\}$ is a set of $m$ programs that have certain characteristics

of the GSCM practices called the universe. $C=\left\{c_{1}, c_{2}, \ldots, c_{\mathrm{n}}\right\}$ is a set of $n$ practices for the GSCM called the condition attributes. $D=\left\{d_{1}, d_{2}, \ldots\right\}$ a specific set of decision attributes representing performance outcomes of programs as defined by decision makers. Where the $f$ is a function used to define the values $V$. In this case $f$ is $U \times C \rightarrow V$ is the description function.

For our illustrative case $U=\left\{P_{\mathrm{i}}, \mathrm{i}=1,2, \ldots, 30\right\}$ (i.e. thirty programs) with thirty conditional attributes $C=\left\{c_{j}, j=1,2,3, \ldots, 30\right\}$. The conditional attributes are represented by the six major practices (subdivided into sub-practices) for GSCM summarized in Table 1. For the illustration we assume two decisions attributes $d_{1}$ and $d_{2}$. $d_{1}$ represents a column whose outcome (decision attribute) is environmentally oriented performance. It can be the amount of wastes generated, resource consumption, or a number of other environmental performance categories. $d_{2}$ represents a column whose outcomes are business-oriented performance. It may include such characteristics of cost, time, quality, flexibility in meeting volume requirements, etc.

\section{Step 2: Evaluate and assign the level of GSCM practice involvement within each program.}

There are two sub-steps in this step. First determine GSCM practice involvement for each program. One way of completing this evaluation is for a team of managers, using historical involvement data, to assign textual perceptual scores ranging from no involvement to very significant practice involvement within each program $\left(V_{c}\right)$. The hypothetical data in this illustrative application is randomly generated by the authors for illustrative purposes. The thirty GSCM practices have information functions that are discrete with 5 levels including No Involvement (NI), Low Involvement (LI), Moderate Involvement (MI), High Involvement (HI) and Full Involvement (FI) depending on level of involvement included in these programs. These discretized values may be determined from either actual or perceptual data. For example, using high amount of energy 
efficient hardware and data centers (GITS1) in a Program 1 will be assigned a textual perceptual value of FI (i.e. $\left.f\left(P_{1}, \mathrm{GITS} 1\right)=\mathrm{FI}\right)$. In some cases perceptual/intangible values may need to be assigned. For example, the jointly develop environmental management solutions GSCM practice may be less tangible and require managerial input on relative participation. Let us assume that managerial input showed that Program 1 had low levels of involvement or participation in the communicate goals of sustainability to suppliers (SSP5), then $f\left(P_{1}, \mathrm{SSP} 5\right)=\mathrm{LI}$.

Second, we make the textual evaluations of each program's performance. The decision attributes (performance data) are also assigned three levels (1- Low performance, 2-Moderate Performance, and 3-High Performance). These values may also be assigned based on actual or perceptual data. Discretizing the information helps in discrimination within the process. Two types of performance data are included for the illustrative application (Environmental and Business performance). The performance outcome and GSCM practice involvement level for each program are shown in Table 3.

\section{[Table 3 about here]}

The decision table to analyze the importance (weight) of each GSCM practice is now completed.

\section{Step 3: Determine GSCM Practice Information Content for Weighting Purposes}

One aspect of rough set theory (RS) is that of attribute reduction. Attribute reduction seeks to remove superfluous attributes from information systems (decision tables) according to an attribute's information content Error! Reference source not found.. In this step we use rough set theory to determine each GSCM practice information content and information content base on the performance outcomes (the decision attributes). To complete these steps, the various 'elementary sets' $(X)$ of GSCM practices for the programs are determined. 
The first step in this process is to determine how the level of information content across the decision attribute $(D)$ in the information system table using the expression (12) based on Liang et al.(2006) .

$$
I(D)=1-\frac{1}{|U|^{2}} \sum_{i=1}^{|U|}\left|X_{i}^{D}\right|
$$

In expression (12) $I(D)$ is the information content ${ }^{8}$ over the decision attribute (in this illustrative case the GSCM program performance outcome), $|U|$ is the cardinality of the universe of programs (30 programs in our example). $\left|X_{i}^{D}\right|$ is the number of programs with similar decision attribute levels for a program $i$.

That is, two programs $i$ and $k$ are members of the same set only if $d(i)=d(k)$ for a decision attribute, where $d$ (i) denotes the value of decision attribute $d$ for program $i$. Expression (13) describes this as a binary relationship between two elements in the set $U$ with complete information (Kryszkiewicz, 1998; Kryszkiewicz, 1999).

$$
\operatorname{SIM}(D)=\{(i, k) \in U \times U \mid \forall d \in D, d(i)=d(k)\}
$$

$X_{i}^{D}$ is defined as the set of $\{i \in U \mid(i, k) \in \operatorname{SIM}(D)\}$. Thus, $X_{i}^{D}$ is the maximal set of objects which are indiscernible by $D$ with program $i$.

The second step in this process is to determine how the level of information content across the conditional attributes $\left(c_{j}\right)$ given the decision attribute $(D)$ by using the expression (14).

$$
I\left(c_{j} \mid D\right)=1-\frac{1}{|U|^{2}} \sum_{i=1}^{|U|}\left|X_{i}\right|
$$

Expression (15) describes this as a binary relationship between two elements in the set $U$ with a decision attribute.

\footnotetext{
${ }^{8}$ This term has also been defined as information entropy of a system (Liang and Shi, 2004).
} 


$$
\operatorname{SIM}\left(c_{j} \mid D\right)=\left\{(i, k) \in U \times U \mid \forall c_{j} \in C, d \in D, c_{j}(i)=c_{j}(k), d(i)=d(k)\right\}
$$

$X_{i}$ is defined as the set of $\left\{i \in U \mid(i, k) \in \operatorname{SIM}\left(c_{j} \mid D\right)\right\}$. Thus, $X_{i}$ is the maximal set of objects which are possibly indiscernible by $c_{j}$ and $D$ with program $i$.

As an example, program 1 has the same decision value as programs 3, 8, 17, 19, 21, and 24 with a similar environmental performance attribute level, thus $\left|X_{1}\right|=7$. This situation also makes $\left|X_{3}\right|$ $=\left|X_{8}\right|=\left|X_{17}\right|=\left|X_{19}\right|=\left|X_{21}\right|=\left|X_{24}\right|=7$. Another, program 1 is in the same GITS1 conditional

attribute level and decision attribute $d_{1}$ as programs 3,8 , and 17 , thus $\left|X_{1}^{d 1}\right|=4$. This situation also makes $\left|X_{3}^{d 1}\right|=\left|X_{8}^{d 1}\right|=\left|X_{17}^{d 1}\right|=4$. See table 4 for the listing of each program information content $\left|\mathrm{X}_{\mathrm{i}}\right|$ and $\left|X_{i}^{d 1}\right|$ within the GITS1 conditional attribute.

\section{[Table 4 about here]}

\section{Step 4: Determine Information Significance and Weight of each GSCM Practice}

We have two sub-steps in this step. First, we identify the information significance of each of the conditional attributes (GSCM Practices). The information significance will help to determine the importance (weight) of practices that provide strong relationships with the performance outcomes.

To determine the information significance of a conditional attribute $\left(\operatorname{Sig}\left(c_{j}\right)\right)$ we use expressions (12), (14) and (16).

$$
\operatorname{Sig}\left(c_{j}\right)=I\left(c_{j} \mid D\right)-I(D)
$$

Expression (16) identifies the difference between the information content of a decision attribute and the information content of the attribute set that does include the conditional attribute. Thus the significance of the GSCM practice GITS1 is written as:

$$
\operatorname{Sig}(\operatorname{GITS} 1)=I(\operatorname{GITS} 1 \mid D)-I(D)
$$


From step 3 we know $I\left(d_{1}\right)=0.607$. Using Expression (14) we calculate $I\left(\right.$ GITS1 $\left.\mid d_{1}\right)=0.889$. Thus, Sig $($ GITS1 $)=0.889-0.607=0.282$. The other GSCM practices' information significances are shown in the Table 5.

Second, we use expression (17) to determine the weight of each GSCM practice according to the information significance.

$$
w\left(c_{j}\right)=\frac{\operatorname{Sig}\left(c_{j}\right)}{\sum_{j=1}^{n} \operatorname{Sig}\left(c_{j}\right)}
$$

The aggregated weight value meets the condition:

$$
\sum_{j=1}^{n} w_{j}=1
$$

where $w_{j}$ is the importance weight for GSCM practice $j$.

For example, the adjusted attribute importance weight for GITS1 $(j=1)$ is:

$$
\begin{aligned}
w_{1} & =\frac{\operatorname{Sig}\left(c_{j}\right)}{\sum_{j=1}^{n} \operatorname{Sig}\left(c_{j}\right)} \\
& =\frac{0.282}{8.144} \\
& =0.0346
\end{aligned}
$$

The final adjusted attribute importance weight values are shown in Table 5.

\section{[Table 5 about here]}

\section{Stage 2: Rank and Select a Suitable Program using Fuzzy-TOPSIS}

\section{Step 5: Conversion of data to a Fuzzy Qualitative Value}

A five level textual scale used in this case example (Table 3) cannot be used in TOPSIS as it currently stands. A fuzzy scale score $\tilde{v}_{i j}$ that can be a good expression of textual language and will 
be used effectively by TOPSIS is introduced. For intangible, textual or qualitative, evaluations, numerical scale tables that would correspond to the triangular fuzzy value are used. For this illustrative case, all the qualitative judgment values range from No Involvement to Full Involvement. The triangular fuzzy values for these qualitative ranges are shown in Table 6.

\section{[Table 6 about here]}

In this case example, as shown in Table 3, the textual valuation for program 1's involvement in practice GITS1 is 'Full Involvement' (FI). Thus the triangular fuzzy scale value for program 1's involvement in practice GITS1 $\left(\tilde{v}_{11}\right)$ is $(0.7,0.9,1)$.

\section{Step 6: Adjust the Importance Weight of GSCM Practices}

In this step we seek to adjust the conditional attribute weight scores determined in step 4 by adjusting these scores for each program $i\left(\tilde{v}_{i j}\right)$ with adjusted attribute $j$ importance weighting $\left(w_{j}\right)$.

A weighted decision matrix is computed by multiplying the importance weights of evaluation criteria and the values in the decision matrix. This step is completed with expression (19) for fuzzy numbers:

$$
v_{i j}=w_{j} \times \tilde{v}_{i j}=\left(w_{j} \times \tilde{v}_{l}^{i j}, w_{j} \times \tilde{v}_{m}^{i j}, w_{j} \times \tilde{v}_{u}^{i j}\right) \forall i \in m
$$

For GSCM program 1, conditional attribute 1 (GITS1) the adjusted triangular fuzzy value is: $v_{11}=w_{1} \times \tilde{v}_{11}=(0.0346 \times 0.7,0.0346 \times 0.9,0.0346 \times 1.00)=(0.0242,0.0311,0.0035)$.

The overall adjusted aggregate attribute scores results for each GSCM program are presented in Table 7.

\section{[Table 7 about here]}

\section{Step 7: Determine the ideal and nadir solution}

The most 'ideal' reference GSCM program $P^{+}$is determined by selecting the maximum value from amongst each of the attributes using expression (4). Thus, we arrive at: 
$P^{+}=\{(0.024,0.031,0.035) 、(0.024,0.031,0.035) 、(0.024,0.031,0.035) 、(0.026,0.034,0.037) 、(0.023,0.03,0.033) 、$

$(0.023,0.029,0.032) 、(0.024,0.031,0.035) 、(0.026,0.033,0.037) 、(0.023,0.029,0.032) 、(0.024,0.031,0.035) 、$

$(0.021,0.028,0.031) 、(0.025,0.032,0.036) 、(0.025,0.032,0.036) 、(0.024,0.03,0.034) 、(0.026,0.034,0.037) 、$

$(0.019,0.024,0.027) 、(0.025,0.032,0.036) 、(0.024,0.03,0.034) 、(0.021,0.027,0.03) 、(0.023,0.03,0.034)$ 、

$(0.021,0.028,0.031) 、(0.022,0.028,0.031) 、(0.022,0.028,0.031) 、(0.022,0.028,0.031) 、(0.023,0.03,0.033) 、$

$(0.015,0.021,0.028) 、(0.024,0.03,0.034) 、(0.025,0.032,0.036) 、(0.022,0.028,0.032) 、(0.024,0.031,0.034)\}$

Second, we will define the nadir reference GSCM program $P^{-}$by selecting the minimum value from amongst each of the attributes using expression (5). Thus, we arrive at:

$P^{-}=\{(0,0.003,0.01) 、(0,0.003,0.01) 、(0,0.003,0.01) 、(0,0.004,0.011) 、(0,0.003,0.01) 、(0,0.003,0.01) 、(0,0.003,0.01) 、$ $(0,0.004,0.011) 、(0,0.003,0.01) 、(0,0.003,0.01) 、(0,0.003,0.009) 、(0,0.004,0.011) 、(0,0.004,0.011) 、(0,0.003,0.01) 、$

$(0,0.004,0.011) 、(0,0.003,0.008) 、(0,0.004,0.011) 、(0,0.003,0.01) 、(0.003,0.009,0.015) 、(0,0.003,0.01) 、(0,0.003,0.009)$

、 $(0,0.003,0.009) 、(0.003,0.009,0.016) 、(0,0.003,0.009) 、(0,0.003,0.01) 、(0,0.003,0.009) 、(0,0.003,0.01) 、$

$(0,0.004,0.011) 、(0,0.003,0.009) 、(0,0.003,0.01)\}$

Step 8: Calculate the separation measures, using the n-dimensional Euclidean distance.

We will determine the difference between the ideal and negative-ideal reference GSCM program and each of the respective comparative GSCM programs separately using expressions (6) and (7). The separations $\mu_{i}^{+}$of each alternative from the ideal solution and the separations $\mu_{i}^{-}$of each alternative from the negative-ideal solution are presented in columns 2 and 3 of Table 8.

\section{[Table 8 about here]}

\section{Step 9: Calculate the relative closeness to the ideal solution.}

The relative closeness of the GSCM program $P_{i}$ with respect to $P^{+}$is calculated using expression

(8). The separations $T_{i}$ of each alternative from the ideal solution are presented in column 4 of Table 7. 
Thus, with a score of 0.723 for the relative closeness, Program 08 is the most preferred GSCM program from among the GSCM programs in the original set. We have just shown the results of an analysis of the GSCM programs given a situation where business-oriented performance is considered.

\section{SENSITIVITY ANALYSIS}

In the initial illustrative example and analysis we rank GSCM programs given a situation where environmentally oriented performance $\left(\mathrm{D}=d_{1}\right)$ is only considered. Additional scenarios could easily be investigated to determine the robustness of the solution given this data set. Two possible scenarios for sensitivity analysis of the solutions include focusing on a different decision attribute (performance measure) or altering the weights of the conditional attributes. In this illustrative sensitivity analysis the sensitivity of the GSCM programs ranking shift is evaluated by first choosing the business decision attribute, and secondly by not considering a variable weighting for the conditional attributes, an equal weighting across all conditional attributes. A sensitivity analysis will help us to determine the impact of changing decision attribute or weight of attributes has on the final ranking solution.

The results of all three scenarios (including the initial scenario case illustration) are shown in Table 8. The results for the best and worse GSCM programs do not change in any of the scenarios, but some ranks of GSCM programs have changed in both scenarios. An example of a shift is the rank of Program05, which went from a rank of 19 when considering environmentally oriented performance as the decision condition, a rank of 21 when considering the business oriented performance decision condition. Program05 ranked 20th when no variations in weight occurred across the conditional attributes. Overall, given these relatively minor shifts, we can state that the solutions are relatively robust and that managers can be relatively confident with the solutions. But, these results are more dependent on the data and the methodology introduced can determine 
robustness. Managers should still be cautious in how they select performance to determine weights and to carefully consider their evaluations.

Practically, these results also symbolize the importance with the decision attributes and provide insights into the possible misapplication of a rough set tool that may have some decisions based on criteria that are only part of the overall decision framework. Another issue is that the organization needs to know how important it is for the company to achieve its environmentally oriented performance relative to its business oriented performance. That is, weighting and integration of multiple dimensions of performance can be integrated into the evaluation. There are many ways to apply these tools and this is just one step in the process.

\section{DISCUSSION AND CONCLUSION}

The environmental issues facing mining organizations are extensive and pervasive. Their impact resonates throughout the supply chain. Thus, understanding how various green supply practices can influence mining industry environmental impact is an issue that requires investigation and evaluation. This paper introduced a comprehensive framework for green supply chain practices that can prove useful to management and researchers. The framework separates the practices into six major factors groupings including Green Information Technology and Systems, Strategic Suppliers Partnership, Operations and Logistics Integration, Internal Environmental Management, Eco-Innovation Practices, and End-of-Life Practices. These factors were separated into 30 subpractices.

The contribution of this work is first that the comprehensive framework presented is the first for investigating GSCM practices within the mining industry. The second contribution was the development of a novel two-stage MCDM methodology that can use this framework.

The comprehensive framework is only one possible framework, others have developed variations and different categories (e.g. Zhu and Sarkis, 2004; Zhu, et al., 2008). The framework was 
practically validated and partially developed using inputs from Ghanaian mining industry managers. But, more thorough scientific and empirical validation is required, especially in the mining industry. Most of the other frameworks developed did not explicitly focus on the mining industry. Thus, this is one of the first that integrates issues facing the mining industry and mining industry input to be developed.

As stated, the utility of this framework was shown through its application of evaluating organizational programs that would seek to implement these practices at some level. Using a novel multiple dimension multiple criteria methodology that integrated, for the first time, rough set theory and fuzzy TOPSIS, an illustrative evaluation was completed to determine how well various programs integrated these practices and their relative influence on overall environmental or business performance. Those programs that showed good performance and integrated significant levels of these practices were then ranked. Programs that covered the largest amount of highly influential on performance green supply practices were ranked more highly.

These factors and the methodology introduced can be used to evaluate other strategic and tactical decisions such as technologies, broader business processes, or even suppliers. Thus, there is flexibility in application of both the framework and the methodology.

Although this research has a number of contributions, limitations and concerns do exist. These limitations also provide ample opportunity for future research directions. For example, the comprehensiveness and applicability of this framework for the mining industry requires additional empirical investigation. Given that only a few managers were asked their opinion, a more careful and scientific evaluation to cover a broader set of organizations, mining industries, and regions are needed to determine how much each of these green supply practices are required or practiced.

From a methodological perspective, the evaluation was completed using hypothetical data. Whether real data can be easily acquired and implemented within these frameworks needs 
investigation. Whether managers find these tools and the results practically useful is another area that requires additional investigation. The tools, although novel and potentially useful, require a more thorough comparative analysis with other tools. For example, other weighting techniques such as the use of scoring or the analytical hierarchy process (AHP) should be compared. The use of rough set is advantageous because the weightings can be determined without any managerial input (if all the data is historical/archival data for instance). AHP would require input from managers in pairwise comparisons. But, whether this rough set weighting advantage offsets the validity of the weights (i.e. are the rough set weights more valid than other techniques' weight determination) needs study.

Extensions of this work can also be completed by determining whether other tools can be integrated (e.g. performance measurement tools to provide initial decision attribute performance values), are additional avenues of future research.

We believe this paper sets an initial foundation for additional and needed research investigation and practical application of green supply practices in the mining industry.

\section{REFERENCES}

Allenby, B. R., Compton, W. D., \& Richards, D. J. (2001). Information systems and the environment: Overview and perspectives. In D. J. Richards, B. R. Allenby, \& W. D. Compton (Eds.), Information systems and the environment. Washington, D.C.: National Academy Press.

Aryee, B. N. (2001). Ghana's mining sector: its contribution to the national economy. Resources Policy, 27(2), 61-75.

Aryee ,B., Aboagye ,Y. (2008). Mining and Sustainable Development in Ghana, Minerals Commission, Ghana

Atkinson, W. (2002). Team turns costs of wastes into profits. Purchasing, 131(8), 22-4.

Awasthi, A., Chauhan, S. S., \& Goyal, S. K. (2010). A fuzzy multicriteria approach for evaluating environmental performance of suppliers. International Journal of Production Economics, 126(2), 370-378. 
Awasthi, A., Chauhan, S. S., \& Omrani, H. (2011). Application of fuzzy TOPSIS in evaluating sustainable transportation systems. Expert systems with Applications, 38(10), 12270-12280.

Awudi B.K, (2002). The Role of Foreign Direct Investment (FDI) in the Mining Sector of Ghana and the environment.

Azevedo, S., Cudney, E.A. Grilo, A., Carvalho, H and Cruz-Machado, V (2012) "The influence of eco-innovation supply chain practices on business eco-efficiency", University of Beira Interior, Missouri University of Science and Technology, Universidade Nova de Lisboa, MPRA Paper No. 42704, posted 18. November 2012 [online] Available from: http://mpra.ub.uni-muenchen.de/42704/ (Assessed: 10 September, 2013)

Bai, C., \& Sarkis, J. (2013). Green information technology strategic justification and evaluation. Information Systems Frontiers, 15(5), 831-847.

Bai, C., \& Sarkis, J. (2010). Integrating sustainability into supplier selection with grey system and rough set methodologies. International Journal of Production Economics, 124(1), 252-264.

Bai, C., Sarkis, J., Wei, X., \& Koh, L. (2012). Evaluating ecological sustainable performance measures for supply chain management. Supply Chain Management: An International Journal, 17(1), 7892.

Baram, M. S., \& Partan, D. G. (1990). Corporate Disclosure of Environmental Risks: US and European Law. Lexis Pub.

Barla, P. (2007). ISO 14001 certification and environmental performance in Quebec's pulp and paper industry. Journal of environmental economics and management, 53(3), 291-306.

Bell, J., Mollenkopf, D. A., \& Stolze, H. (2013). Natural resource scarcity and the closed-loop supply chain: a resource-advantage view. International Journal of Physical Distribution \& Logistics Management, $43(5), 2-12$

Berl, A., Gelenbe, E., Di Girolamo, M., Giuliani, G., De Meer, H., Dang, M. Q., \& Pentikousis, K. (2010). Energy-efficient cloud computing. The Computer Journal, 53(7), 1045-1051.

Bloch, R., \& Owusu, G. (2012). Linkages in Ghana's gold mining industry: Challenging the enclave thesis. Resources Policy, 37(4), 434-442.

Boon, E. K., \& Ababio, F. (2009, May). Corporate Social Responsibility in Ghana: Lessons from the mining sector. In IAIIA09 Conference Proceedings, Impact Assessment and Human Well-Being.

Bowen, F. E., Cousins, P. D., Lamming, R. C., \& Farukt, A. C. (2001). The role of supply management capabilities in green supply. Production and operations management, 10(2), 174-189.

Brandenburg, M., Govindan, K., Sarkis, J., \& Seuring, S. (2014). Quantitative models for sustainable supply chain management: Developments and directions. European Journal of Operational Research, 233(2), 299-312. 
Carter, C. R., \& Easton, P. L. (2011). Sustainable supply chain management: evolution and future directions. International Journal of Physical Distribution \& Logistics Management, 41(1), 46-62.

Chen, C. T. (2000). Extensions of the TOPSIS for group decision-making under fuzzy environment. Furzy sets and systems, 114(1), 1-9.

Chen, I. J., \& Paulraj, A. (2004). Towards a theory of supply chain management: the constructs and measurements. Journal of operations management, 22(2), 119-150.

Chen, M. F., \& Tzeng, G. H. (2004). Combining grey relation and TOPSIS concepts for selecting an expatriate host country. Mathematical and Computer Modelling, 40(13), 1473-1490.

Chen, S. J. J., Hwang, C. L., Beckmann, M. J., \& Krelle, W. (1992). Furay multiple attribute decision making: methods and applications. Springer-Verlag New York, Inc.

Cheng, J. H., Chen, H. P., \& Lin, Y. M. (2010). A hybrid forecast marketing timing model based on probabilistic neural network, rough set and C4. 5. Expert systems with Applications, 37(3), 1814-1820

Chou, D. C., \& Chou, A. Y. (2012). Awareness of Green IT and its value model. Computer Standards \&Interfaces, 34(5), 447-451.

Christopher, M., (2005). Logistics and Supply Chain Management: Creating Value-adding Networks. $3^{\text {rd }}$ ed., Prentice-Hall, Englewood Cliffs, NJ

Christopher, M. (2010). Logistics and supply chain management. $4^{\text {th }}$ ed., Financial Times/Prentice Hall, London

Cottrill, K. (1997). Turning trash into profit. Journal of Business Strategy, 18(4), 30-35.

Curkovic, S., Melnyk, S. A., Handfield, R. B., \& Calantone, R. (2000). Investigating the Linkage Between Total Quality Management and Environmentally Responsible Manufacturing. IEEE Transactions on Engineering Management, 47(4), 444-463

Dobele, A. R., Westberg, K., Steel, M., \& Flowers, K. (2014). An examination of corporate social responsibility implementation and stakeholder engagement: A case study in the Australian mining industry. Business Strategy and the Environment, 23(3), 145-159.

Driussi, C., \& Jansz, J. (2006). Technological options for waste minimisation in the mining industry. Journal of Cleaner Production, 14(8), 682-688.

Dubois, D., \& Prade, H. (1980). Systems of linear fuzzy constraints. Fuzzy Sets and Systems, 3(1), $37-$ 48.

Eswaraiah, C. Biswal, S.K. and Mishra, B.K. (2012). Settling characteristics of ultrafine iron ore slimes, International Journal of Minerals, Metallurgy and Materials, 19(2), 95-99. 
Faucheux, S., \& Nicolaï, I. (2011). IT for green and green IT: A proposed typology of ecoinnovation. Ecological Economics, 70(11), 2020-2027.

Geffen, C. A., \& Rothenberg, S. (2000). Suppliers and environmental innovation: the automotive paint process. International Journal of Operations \& Production Management, 20(2), 166-186.

Govindan, K., Khodaverdi, R., \& Jafarian, A. (2013). A fuzzy multi criteria approach for measuring sustainability performance of a supplier based on triple bottom line approach. Journal of Cleaner Production, 47, 345-354.

Gunasekaran, A., \& Ngai, E. W. (2004). Information systems in supply chain integration and management. European Journal of Operational Research, 159(2), 269-295.

Gunasekaran, A., Patel, C., \& Tirtiroglu, E. (2001). Performance measures and metrics in a supply chain environment. International journal of operations \& production Management, 21(1/2), 71-87.

Gunasekaran, A., Patel, C., \& McGaughey, R. E. (2004). A framework for supply chain performance measurement. International journal of production economics, 87(3), 333-347.

Hilson, G. (2000). Barriers to implementing cleaner technologies and cleaner production (CP) practices in the mining industry: a case study of the Americas. Minerals Engineering, 13(7), 699-717.

Hilson, G., \& Nayee, V. (2002). Environmental management system implementation in the mining industry: a key to achieving cleaner production. International journal of mineral processing, 64(1), 19-41.

Huang, I. B., Keisler, J., \& Linkov, I. (2011). Multi-criteria decision analysis in environmental sciences: ten years of applications and trends. Science of the total environment, 409(19), 3578-3594.

Hwang, C. L., \& Yoon, K. (1981). Multiple attribute decision making. Berlin: Springer.

Jenkin, T. A., Webster, J., \& McShane, L. (2011). An agenda for 'Green'information technology and systems research. Information and Organization, 21(1), 17-40.

Jia, P., Diabat, A., \& Mathiyazhagan, K. (2014). Analyzing the SSCM practices in the mining and mineral industry by ISM approach. Resources Policy.

Kemp, R. and T. Foxon (2007). Eco-innovation from an innovation dynamics perspective: Deliverable 1 of MEI project (D1). Project Report [online].Available from: http://www.merit.unu.edu/MEI/ (Assessed: 10 September, 2013)

Kleindorfer, P. R., Singhal, K., \& Wassenhove, L. N. (2005). Sustainable operations management. Production and operations management, 14(4), 482-492.

Krohling, R. A., \& Campanharo, V. C. (2011). Fuzzy TOPSIS for group decision making: A case study for accidents with oil spill in the sea. Expert Systems with Applications, 38(4), 4190-4197.

Kryszkiewicz, M. (1998). Rough set approach to incomplete information systems. Information sciences, 112(1), 39-49. 
Kryszkiewicz, M. (1999). Rules in incomplete information systems. Information Sciences, 113(3), 271 292.

Lenzen, M., Murray, J., Sack, F., \& Wiedmann, T. (2007). Shared producer and consumer responsibility—theory and practice. Ecological Economics, 61(1), 27-42.

Liang, J., Shi, Z., Li, D., \& Wierman, M. J. (2006). Information entropy, rough entropy and knowledge granulation in incomplete information systems. International Journal of general systems, 35(6), 641-654.

Li, D. F. (2012). A fast approach to compute fuzzy values of matrix games with payoffs of triangular fuzzy numbers. European Journal of Operational Research, 223(2), 421-429.

Lutandula, M. S., \& Maloba, B. (2013). Recovery of cobalt and copper through reprocessing of tailings from flotation of oxidised ores. Journal of Environmental Chemical Engineering, 1(4), 1085-1090.

Mbendi, (1995-2013), Mining in Ghana-Overview, [online]. Available from:

http://www.mbendi.com/indy/ming/af/gh/p0005.htm (Assessed: 10 April, 2013)

Mentzer, J. T., Min, S., \& Zacharia, Z. G. (2000). The nature of interfirm partnering in supply chain management. Journal of Retailing, 76(4), 549-568

Min, H., \& Galle, W. P. (2001). Green purchasing practices of US firms. International Journal of Operations \& Production Management, 21(9), 1222-1238.

Muduli, K., Govindan, K., Barve, A., Kannan, D., \& Geng, Y. (2013). Role of behavioural factors in green supply chain management implementation in Indian mining industries. Resources, Conservation and Recycling, 76: 50-60

Mzembe, A. N., \& Meaton, J. (2013). Driving Corporate Social Responsibility in the Malawian Mining Industry: A Stakeholder Perspective. Corporate Social Responsibility and Environmental Management. Forthcoming, DOI: 10.1002/csr.1319.

Opricovic, S., \& Tzeng, G. H. (2004). Compromise solution by MCDM methods: A comparative analysis of VIKOR and TOPSIS. European Journal of Operational Research, 156(2), 445-455.

Paulraj, A. (2009). Environmental motivations: a classification scheme and its impact on environmental strategies and practices. Business Strategy and the Environment, 18(7), 453-468.

Pawlak, Z. (1982). Rough sets. International Journal of Computer \& Information Sciences, 11(5), 341-356.

Poulton, M. M., Jagers, S. C., Linde, S., Van Zyl, D., Danielson, L. J., \& Matti, S. (2013). State of the World s Nonfuel Mineral Resources: Supply, Demand, and Socioinstitutional Fundamentals. Annual Review of Environment and Resources, 38(1), 345-371.

Rao, P. (2002). Greening the supply chain: a new initiative in South East Asia. International Journal of Operations \& Production Management, 22(6), 632-655. 
Rao, P., \& Holt, D. (2005). Do green supply chains lead to competitiveness and economic performance?. International Journal of Operations \& Production Management, 25(9), 898-916.

Rath, R. K., Hiroyoshi, N., Tsunekawa, M., \& Hirajima, T. (2003). Ammoniacal thiosulphate leaching of gold ore. ejmp \& ep (European Journal of Mineral Processing and Environmental Protection), 3(3), 344-352.

Rogers, D. S., \& Tibben-Lembke, R. (2001). An examination of reverse logistics practices. Journal of business Logistics, 22(2), 129-148.

Sarkis, J., \& Cordeiro, J. J. (2001). An empirical evaluation of environmental efficiencies and firm performance: pollution prevention versus end-of-pipe practice. European Journal of Operational Research, 135(1), 102-113.

Sarkis, J. (2003). A strategic decision framework for green supply chain management. Journal of cleaner production, 11(4), 397-409.

Sarkis, J., \& Zhu, H. (2008). Information technology and systems in China's circular economy: implications for sustainability. Journal of Systems and Information Technology, 10(3), 202-217.

Soltanmohammadi, H., Osanloo, M., \& Bazzazi, A. A. (2009). Deriving preference order of postmining land-uses through MLSA framework: application of an outranking technique. Environmental geology, 58(4), 877-888.

Setterstrom, A. (2008). The natural resource-base view of a firm: Strategic opportunities in IT. Paper presented at the Annual Academy of Management Meetings, Anaheim, CA

Seuring, S. (2013). A review of modeling approaches for sustainable supply chain management. Decision Support Systems, 54(4), 1513-1520.

Shyng, J. Y., Shieh, H. M., \& Tzeng, G. H. (2010). An integration method combining Rough Set Theory with formal concept analysis for personal investment portfolios. Knowledge-Based Systems, 23(6), 586-597.

Simpson, D. F., \& Power, D. J. (2005). Use the supply relationship to develop lean and green suppliers. Supply Chain Management: An International Journal, 10(1), 60-68.

Simpson, D., Power, D., \& Samson, D. (2007). Greening the automotive supply chain: a relationship perspective. International Journal of Operations \& Production Management, 27(1), 28-48.

Sivakumar, R., Devika Kannan, and P. Murugesan. (2014). Green vendor evaluation and selection using AHP and Taguchi loss functions in production outsourcing in mining industry. Resources Policy.

Spekman, R. E., \& Carraway, R. (2006). Making the transition to collaborative buyer-seller relationships: An emerging framework. Industrial Marketing Management, 35(1), 10-19. 
Stock, G. N., Greis, N. P., \& Kasarda, J. D. (1999). Logistics, strategy and structure: a conceptual framework. International Journal of Physical Distribution \& Logistics Management, 29(4), 224-239.

Stock, G. N., Greis, N. P., \& Kasarda, J. D. (2000). Enterprise logistics and supply chain structure: the role of fit. Journal of Operations Management, 18(5), 531-547.

Stock, J. R. (2001). Reverse logistics in the supply chain. Revista Transport \& Logistics, 44.

Tan, K.C., Lyman, S., \& Wisner, J. (2002). Supply chain management: a strategic perspective. International Journal of Operations and Production Management, 22 (6), 614-631.

Tuzkaya, G., Ozgen, A., Ozgen, D., \& Tuzkaya, U. R. (2009). Environmental performance evaluation of suppliers: A hybrid fuzzy multi-criteria decision approach. International Journal of Environmental Science \& Technology, 6(3), 477-490.

Uddin, M., \& Rahman, A. A. (2012). Energy efficiency and low carbon enabler green IT framework for data centers considering green metrics. Renewable and Sustainable Energy Reviews, 16(6), 4078-4094.

Vachon, S. (2007). Green supply chain practices and the selection of environmental technologies. International Journal of Production Research, 45(18-19), 4357-4379.

Vachon, S. (2013). Technological Capacity and Environmental Performance: A Research Note Using Country Level Data. Journal of Operations and Supply Chain Management, 1(1), 21-28.

Vachon, S., \& Klassen, R. D. (2006a). Extending Green Practices across the Supply Chain: The Impact of Upstream and Downstream Integration. International Journal of Operations and Production Management, 26(7), 795-821.

Vachon, S., \& Klassen, R. D. (2006b). Green Project Partnership in the Supply Chain: The Case of the Package Printing Industry. Journal of Cleaner Production, 14(6-7), 661-671.

Vachon, S., \& Klassen, R. D. (2008). Environmental management and manufacturing performance: the role of collaboration in the supply chain. International Journal of Production Economics, 111(2), 299315.

Vachon, S., \& Mao, Z. (2008). Linking Supply Chain Strength to Sustainable Development: A Country-Level Analysis. Journal of Cleaner Production, 16(15), 1552-1560.

Vachon, S., Klassen, R.D. and Johnson, P.F. (2001). Customers as Green Suppliers: Managing the Complexity of the Reverse Supply Chain. In Greening Manufacturing: From Design to Delivery and Back, edited by J. Sarkis, (Greenleaf publisher: Sheffield, UK).

Wagner, S., Hespenheide, E., \& Pavlovsky, K. (2009). The responsible and sustainable board. Deloitte Review Issue, 4, 59-71. 
Watson, R. T., Boudreau, M. C., Chen, A., \& Huber, M. H. (2008). Green IS: Building sustainable business practices. In R. T. Watson (Ed.), Information Systems. Athens, GA, USA: Global Text Project

Wee, Y. S., \& Quazi, H. A. (2005). Development and validation of critical factors of environmental management. Industrial Management \& Data Systems, 105(1), 96-114.

Wang, X., \& Gaustad, G. (2012). Prioritizing material recovery for end-of-life printed circuit boards. Waste Management, 32(10), 1903-1913.

Wang, X., \& Chan, H. K. (2013). A hierarchical fuzzy TOPSIS approach to assess improvement areas when implementing green supply chain initiatives. International Journal of Production Research, 51(10), 3117-3130.

Yu, V. F., \& Hu, K. J. (2010). An integrated fuzzy multi-criteria approach for the performance evaluation of multiple manufacturing plants. Computers \& Industrial Engineering, 58(2), 269-277.

Zhu, Q., \& Sarkis, J. (2004). Relationships between operational practices and performance among early adopters of green supply chain management practices in Chinese manufacturing enterprises. Journal of Operations Management, 22(3), 265-289.

Zhu, Q., Sarkis, J., \& Lai, K. H. (2008). Confirmation of a measurement model for green supply chain management practices implementation. International Journal of Production Economics, 111(2), 261-273.

Zsidisin, G. A., \& Hendrick, T. E. (1998). Purchasing's involvement in environmental issues: a multi-country perspective. Industrial Management \& Data Systems, 98(7), 313-320. 


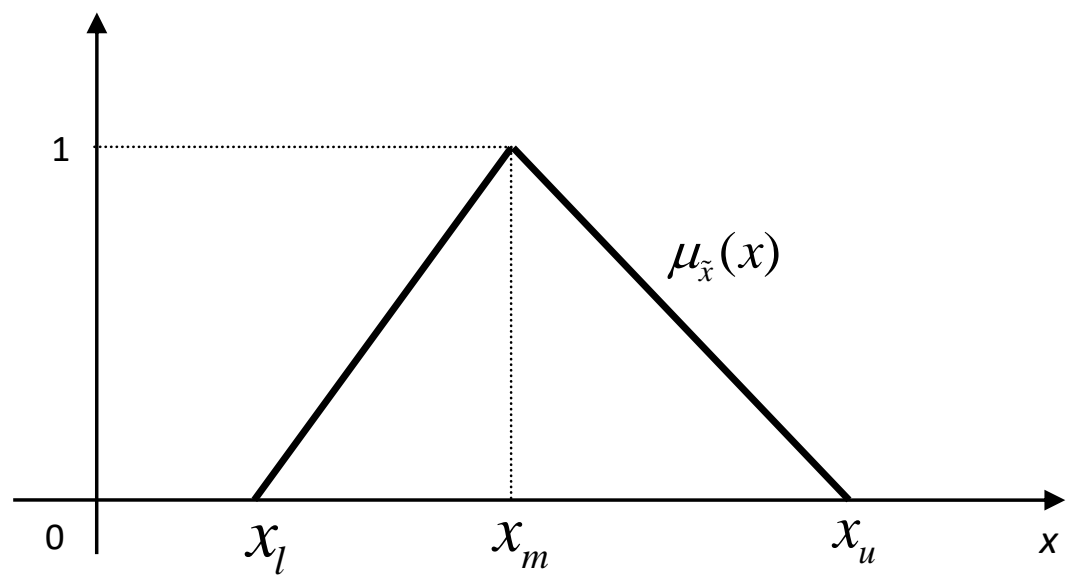

Figure 1 A triangular fuzzy number $\tilde{x}$ 
Table 1. GSCM practices (factors) and their sub-factors in the mining industry

\begin{tabular}{|c|c|c|c|}
\hline Pos & & GSCM Factors and Sub-factors & Literature \\
\hline 1 & \multicolumn{2}{|c|}{ Green Information Technology and Systems (GITS) } & \\
\hline \multirow{5}{*}{ 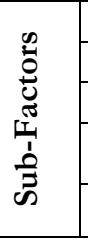 } & GITS1 & Use of energy efficient hardware and data centers & \multirow{5}{*}{$\begin{array}{l}\text { Watson et al., 2008; } \\
\text { Jenkin et al., 2011; Chou } \\
\text { et al., 2012; Setterstrom, } \\
\text { 2008; Sarkis and Zhu, } \\
\text { 2008: Wagner et al., 2009; } \\
\text { Uddin and Rahman, 2012 }\end{array}$} \\
\hline & GITS2 & Consolidating servers using virtualization software & \\
\hline & GITS3 & Reducing waste associated with obsolete equipment & \\
\hline & GITS4 & Collaborative group software and telepresence systems & \\
\hline & GITS5 & Eco-labeling of IT products & \\
\hline 2 & \multicolumn{2}{|c|}{ Strategic Suppliers Partnership (SSP) } & \\
\hline \multirow{6}{*}{ 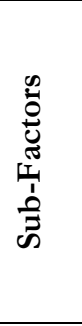 } & SSP1 & Jointly develop environmental management solutions & \multirow{6}{*}{$\begin{array}{l}\text { Vachon et al. 2001; Rao } \\
\text { 2002; Geffen and } \\
\text { Rothenberg 2000, } \\
\text { Simpson and Power, } \\
\text { 2005; Simpson et al., } 2007\end{array}$} \\
\hline & SSP2 & Jointly build programs to reduce or eliminate materials use & \\
\hline & SSP3 & Share environmental management techniques and knowledge & \\
\hline & SSP4 & $\begin{array}{l}\text { Collaborate with suppliers to manage reverse flows of } \\
\text { materials and packaging }\end{array}$ & \\
\hline & SSP5 & Communicate goals of sustainability to suppliers & \\
\hline & SSP6 & $\begin{array}{l}\text { Monitor environmental compliance status and practices of } \\
\text { supplier's operations }\end{array}$ & \\
\hline 3 & \multicolumn{2}{|c|}{ Operations and Logistics Integration (OLI) } & \\
\hline \multirow{4}{*}{  } & OLI1 & Lean and green operations & \multirow{4}{*}{$\begin{array}{c}\text { Kleindorfer, 2005; } \\
\text { Hajmohammed et al., } \\
\text { 2012; Vachon, 2007; Wee } \\
\text { \& Quazi, 2005; Min and } \\
\text { Galle, 2001; Carter and } \\
\text { Easton, 2011; Zsidisin } \\
\text { and Hendrick, } 1998\end{array}$} \\
\hline & OLI2 & $\begin{array}{l}\text { Process redesign to reduce use of scarce or toxic resources } \\
\text { and energy consumption }\end{array}$ & \\
\hline & OLI3 & $\begin{array}{l}\text { Community/environmental, employee health and safety } \\
\text { concerns }\end{array}$ & \\
\hline & OLI4 & Internal process integration and production automation & \\
\hline 4 & \multicolumn{2}{|c|}{ Internal Environmental Management (IEM) } & \\
\hline \multirow{6}{*}{ 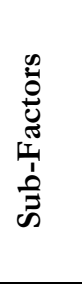 } & IEM1 & Total quality environment management & \multirow{6}{*}{$\begin{array}{c}\text { Vachon and Klassen, } \\
\text { 2008; Min and Gall, 2001; } \\
\text { Azevedo et al., 2012; } \\
\text { Simpson et al., 2007; } \\
\text { Vachon and Klassen, } \\
\text { 2006a; Baram and Partan, } \\
1990\end{array}$} \\
\hline & IEM2 & Environmental compliance monitoring and auditing & \\
\hline & IEM3 & Pollution prevention plans & \\
\hline & IEM4 & Environmental manager and training for employees & \\
\hline & IEM5 & $\begin{array}{l}\text { Environmental standards/ISO14001 certification by } \\
\text { suppliers }\end{array}$ & \\
\hline & IEM6 & Employee incentive programs for environmental suggestions & \\
\hline 5 & \multicolumn{2}{|c|}{ Eco-Innovation practices(ECO) } & \\
\hline \multirow{4}{*}{ 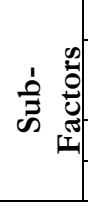 } & ECO1 & Substituting toxic inputs with environmentally friendly ones & \multirow{4}{*}{$\begin{array}{c}\text { Carter and Easton, 2011; } \\
\text { Vachon, 2013; Azevedo } \\
\text { et al., 2012; Paulraj, 2009; } \\
\text { Rao \& Holt, } 2005\end{array}$} \\
\hline & ECO2 & $\begin{array}{l}\text { Use of fewer inputs to minimize the environmental risks and } \\
\text { impacts }\end{array}$ & \\
\hline & ECO3 & Switching from "dirty" to cleaner technologies & \\
\hline & ECO4 & Internal recycling of inputs, materials and wastes & \\
\hline 6 & \multicolumn{2}{|c|}{ End-of-Life practices (EOL) } & \\
\hline \multirow{5}{*}{ 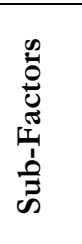 } & EOL1 & Resale of used parts or components & \multirow{5}{*}{$\begin{array}{c}\text { Stock, 2001; Sarkis, 2003; } \\
\text { Rogers and Tibben- } \\
\text { Lembke, 2001; Bell et al., } \\
2013\end{array}$} \\
\hline & EOL2 & Recondition and refurbishing of used parts or components & \\
\hline & EOL3 & Old/obsolete items being replaced & \\
\hline & EOL4 & $\begin{array}{l}\text { Cyanide and arsenic solution recovery and carbon } \\
\text { regeneration }\end{array}$ & \\
\hline & EOL5 & Mining of Tailings & \\
\hline
\end{tabular}


Table.2 Overview of Rough set and fuzzy-TOPSIS methodology for Green Supply Chain Practices

\begin{tabular}{|c|c|c|}
\hline No & Activity & Activity description \\
\hline \multicolumn{3}{|c|}{ Stage 1: Identify the Importance (Weight) of GSCM Practices by Rough Set } \\
\hline $\begin{array}{c}\text { Step } \\
1\end{array}$ & $\begin{array}{l}\text { Build Original Decision System } \\
\text { (Table) }\end{array}$ & $\begin{array}{l}\text { The decision table should be comprised of matrix } \\
\text { with } m \text { programs (evaluation alternatives) in the row } \\
\text { and } n \text { practices (criteria to be used in evaluating the } \\
\text { programs/alternatives) and } k \text { performance } \\
\text { outcomes. }\end{array}$ \\
\hline $\begin{array}{c}\text { Step } \\
2\end{array}$ & $\begin{array}{l}\text { Evaluate and assign the level of } \\
\text { GSCM practice involvement } \\
\text { within each program }\end{array}$ & $\begin{array}{l}\text { Sub-step 1. Managers can allocate historic data to } \\
\text { each cell in the matrix or evaluate the importance of } \\
\text { each practice on each program and assign perceptual } \\
\text { data using the 5-point measurement scale from No } \\
\text { Involvement (NI) to Full Involvement (FI). } \\
\text { Sub-step 2. Managers allocate another set of } \\
\text { actual/historic data of the importance of each } \\
\text { program on the performance outcome or perceptual } \\
\text { data are assigned using a } 3 \text { point measurement scale } \\
\text { (1- Low performance, 2-Moderate Performance, and } \\
\text { 3-High Performance). }\end{array}$ \\
\hline $\begin{array}{l}\text { Step } \\
3\end{array}$ & $\begin{array}{l}\text { Determine GSCM Practice } \\
\text { Information Content for } \\
\text { Weighting Purposes }\end{array}$ & $\begin{array}{l}\text { Sub-step 1. Information content for each decision } \\
\text { attributes/variables with respect to the programs is } \\
\text { determined. } \\
\text { Sub-step 2. Information content for each of the } \\
\text { conditional attributes/evaluation criteria (e.g. GITS1) } \\
\text { is determined. }\end{array}$ \\
\hline $\begin{array}{c}\text { Step } \\
4\end{array}$ & $\begin{array}{l}\text { Determine Information } \\
\text { Significance and Weight of each } \\
\text { GSCM Practice }\end{array}$ & $\begin{array}{l}\text { Sub-step 1. Information significance of the each } \\
\text { conditional attribute or evaluation criteria is } \\
\text { determined by the difference between the } \\
\text { information content for a specific conditional } \\
\text { attribute/evaluation criterion, for a given decision } \\
\text { attribute/variable, and information content for other } \\
\text { decision attributes/variables. } \\
\text { Sub-step } 2 \text {. The weight of each conditional } \\
\text { attribute/evaluation criterion according to the } \\
\text { information significance is determined by dividing } \\
\text { the information significance of each conditional } \\
\text { attribute/criterion by the total information } \\
\text { significance in the evaluation table }\end{array}$ \\
\hline \multicolumn{3}{|c|}{ Stage 2: Rank and Select a Suitable Program using Fuzzy-TOPSIS } \\
\hline $\begin{array}{c}\text { Step } \\
5\end{array}$ & $\begin{array}{l}\text { Conversion of data to a Fuzzy } \\
\text { Qualitative Value }\end{array}$ & $\begin{array}{l}\text { Equivalent triangular fuzzy values are used to replace } \\
\text { the textual scale to assign the values in the decision } \\
\text { table. }\end{array}$ \\
\hline $\begin{array}{c}\text { Step } \\
6\end{array}$ & $\begin{array}{l}\text { Adjust the Importance Weight of } \\
\text { GSCM Practices }\end{array}$ & $\begin{array}{l}\text { A weighted decision matrix is computed by } \\
\text { multiplying the importance weights of each } \\
\text { corresponding evaluation criterion in the decision } \\
\text { matrix. }\end{array}$ \\
\hline Step & Determine the ideal and nadir & Sub-step 1. The 'ideal' reference value for evaluation \\
\hline
\end{tabular}




\begin{tabular}{|c|c|c|}
\hline 7 & solution & $\begin{array}{l}\text { program } P^{+} \text {is determined by selecting the } \\
\text { maximum value from each of the } \\
\text { attributes/evaluation criteria. } \\
\text { Sub-step } 2 \text {. The 'nadir' reference of the evaluation } \\
\text { program } P^{-} \text {is determined by selecting the minimum } \\
\text { value from amongst each of the attributes/evaluation } \\
\text { criteria }\end{array}$ \\
\hline $\begin{array}{c}\text { Step } \\
8\end{array}$ & $\begin{array}{l}\text { Calculate the separation measures, } \\
\text { using the n-dimensional } \\
\text { Euclidean distance. }\end{array}$ & $\begin{array}{l}\text { Sub-step 1. The separation of each alternative from } \\
\text { the ideal solution is determined } \\
\text { Sub-step } 2 \text {. The separation of each alternative from } \\
\text { the nadir solution is determined }\end{array}$ \\
\hline $\begin{array}{c}\text { Step } \\
9\end{array}$ & $\begin{array}{l}\text { Calculate the relative closeness to } \\
\text { the ideal solution and rank the } \\
\text { preference order. }\end{array}$ & $\begin{array}{l}\text { Sub-step 1. The relative closeness of the alternative } \\
P_{i} \text { (e.g. Program 1) with respect to } P^{+} \text {('ideal' } \\
\text { reference) is computed. } \\
\text { Sub-step } 2 \text {. The ranking of the preference order is } \\
\text { then followed. The larger the value of } T_{i} \text { (relative } \\
\text { closeness), the better the alternative } P_{i} \text {. Thus, the } \\
\text { best alternative is the one with the greatest relative } \\
\text { closeness to the ideal solution. }\end{array}$ \\
\hline
\end{tabular}


Table 3: Information System Table for GSCM practices Involvement and Normalized Aggregate Performance Outcome.

\begin{tabular}{|c|c|c|c|c|c|c|c|c|c|c|c|c|c|c|c|c|c|c|c|c|c|c|c|c|c|c|c|c|c|c|c|c|}
\hline & \multicolumn{5}{|c|}{$\begin{array}{c}\text { Green Information Technology and } \\
\text { Systems (GITS) }\end{array}$} & \multicolumn{6}{|c|}{ Strategic Suppliers Partnership (SSP) } & \multicolumn{4}{|c|}{$\begin{array}{c}\text { Operations and logistics } \\
\text { integration (IOLI) }\end{array}$} & \multicolumn{6}{|c|}{ Internal environmental management (IEM) } & \multicolumn{4}{|c|}{ Eco-innovation practices(ECO) } & \multicolumn{5}{|c|}{ End-of-life practices (EOL) } & \multicolumn{2}{|c|}{$\begin{array}{c}\text { Performan } \\
\text { ce }\end{array}$} \\
\hline & $\begin{array}{l}\text { GIT } \\
\mathrm{S} 1\end{array}$ & $\begin{array}{l}\text { GIT } \\
\mathrm{S}_{2}\end{array}$ & $\begin{array}{l}\text { GIT } \\
\mathrm{S}_{3}\end{array}$ & $\begin{array}{l}\mathrm{GIT} \\
\mathrm{S} 4\end{array}$ & $\begin{array}{l}\text { GIT } \\
\mathrm{S}_{5}\end{array}$ & $\begin{array}{l}\text { ss } \\
\text { P1 }\end{array}$ & $\begin{array}{ll}\text { ss } \\
\text { P2 }\end{array}$ & $\begin{array}{ll}\text { ss } \\
\text { P3 }\end{array}$ & $\begin{array}{ll}\text { ss } \\
\text { P4 }\end{array}$ & $\begin{array}{l}\text { ss } \\
\text { P5 }\end{array}$ & $\begin{array}{l}\begin{array}{l}\text { ss } \\
\text { P6 }\end{array} \\
\end{array}$ & $\begin{array}{l}\text { OLI } \\
1\end{array}$ & $\begin{array}{l}\text { OLI } \\
2\end{array}$ & $\begin{array}{l}\text { OLI } \\
3\end{array}$ & $\begin{array}{l}\text { OLI } \\
4\end{array}$ & $\begin{array}{l}\mathrm{IE} \\
\mathrm{M} 1\end{array}$ & $\begin{array}{l}\mathrm{IE} \\
\mathrm{M} 2\end{array}$ & $\begin{array}{ll}\mathrm{IE} \\
\mathrm{M} 3\end{array}$ & $\begin{array}{l}\mathrm{IE} \\
\mathrm{M} 4\end{array}$ & $\begin{array}{l}\mathrm{IE} \\
\mathrm{M} 5\end{array}$ & $\begin{array}{l}\mathrm{IE} \\
\mathrm{M} 6\end{array}$ & $\begin{array}{l}\mathrm{EC} \\
\mathrm{O} 1\end{array}$ & $\begin{array}{l}\mathrm{EC} \\
\mathrm{OC}\end{array}$ & $\begin{array}{l}\mathrm{EC} \\
03\end{array}$ & $\begin{array}{l}\mathrm{EC} \\
\mathrm{O} 4\end{array}$ & $\begin{array}{l}\text { EO } \\
\text { L1 }\end{array}$ & \begin{tabular}{|l|} 
EO \\
L2
\end{tabular} & $\begin{array}{l}\begin{array}{l}\text { EO } \\
\text { L3 }\end{array} \\
\end{array}$ & $\begin{array}{l}\text { EO } \\
\text { L4 }\end{array}$ & $\begin{array}{ll}\text { EO } \\
\mathrm{L} 5\end{array}$ & d1 & \\
\hline Program01 & FI & MI & FI & MI & HI & FI & FI & HI & FI & LI & MI & FI & MI & HI & FI & LI & FI & $\mathrm{HI}$ & HI & HI & NI & HI & HI & HI & NI & LI & NI & $\mathrm{HI}$ & MI & $\mathrm{HI}$ & 3 & \\
\hline Program02 & LI & MI & NI & $\mathrm{HI}$ & NI & MI & HI & MI & MI & HI & MI & HI & HI & LI & FI & LI & HI & NI & LI & NI & MI & LI & MI & LI & NI & HI & NI & NI & NI & NI & 1 & \\
\hline Program03 & FI & FI & MI & LI & MI & $\mathrm{HI}$ & $\mathrm{HI}$ & FI & MI & MI & HI & LI & FI & MI & MI & $\mathrm{HI}$ & MI & $\mathrm{HI}$ & FI & $\mathrm{HI}$ & NI & FI & FI & HI & NI & $\mathrm{HI}$ & FI & $\mathrm{HI}$ & MI & FI & 3 & \\
\hline Program04 & LI & MI & NI & HI & NI & LI & LI & NI & NI & LI & FI & LI & NI & NI & HI & FI & MI & NI & MI & MI & NI & LI & FI & NI & MI & HI & MI & MI & LI & FI & 1 & \\
\hline Program05 & $\mathrm{HI}$ & FI & LI & LI & FI & MI & $\mathrm{HI}$ & LI & MI & $\mathrm{NI}$ & MI & NI & LI & NI & LI & MI & LI & MI & LI & FI & LI & MI & HI & FI & LI & MI & LI & $\mathrm{HI}$ & NI & HI & 2 & \\
\hline $\begin{array}{l}\text { Program06 } \\
\end{array}$ & LI & FI & MI & LI & HI & FI & FI & MI & LI & FI & LI & MI & HI & FI & LI & MI & LI & MI & MI & MI & NI & LI & FI & NI & MI & HI & MI & FI & LI & HI & 2 & \\
\hline $\begin{array}{l}\text { Program07 } \\
\end{array}$ & LI & FI & MI & LI & HI & FI & FI & MI & MI & HI & MI & HI & HI & LI & FI & LI & HI & LI & MI & NI & MI & NI & LI & NI & LI & MI & LI & MI & FI & NI & 2 & \\
\hline Program08 & FI & LI & MI & HI & MI & FI & HI & $\mathrm{HI}$ & FI & HI & NI & HI & FI & HI & NI & MI & $\mathrm{HI}$ & $\mathrm{HI}$ & FI & $\mathrm{HI}$ & MI & FI & HI & HI & FI & MI & FI & HI & FI & HI & 3 & \\
\hline $\begin{array}{l}\text { Program09 } \\
\end{array}$ & MI & LI & FI & $\mathrm{HI}$ & LI & MI & MI & FI & FI & MI & LI & NI & HI & HI & MI & LI & MI & MI & MI & HI & MI & HI & HI & LI & FI & LI & HI & FI & LI & HI & 2 & \\
\hline Program10 & MI & LI & MI & FI & LI & LI & NI & MI & LI & MI & FI & LI & LI & NI & NI & HI & NI & LI & MI & $\mathrm{N}$ & $\mathrm{MI}$ & NI & LI & MI & LI & MI & LI & LI & LI & FI & & \\
\hline Program11 & HI & HI & LI & FI & HI & FI & HI & NI & LI & NI & MI & LI & MI & LI & NI & HI & NI & FI & LI & MI & MI & MI & HI & HI & LI & MI & FI & FI & NI & FI & 2 & \\
\hline Program12 & $\mathrm{NI}$ & LI & MI & LI & MI & $\begin{array}{ll}\text { LI } \\
\end{array}$ & MI & LI & LI & LI & MI & NI & NI & LI & MI & LI & NI & NI & FI & LI & MI & LI & MI & LI & MI & LI & MI & NI & NI & $\mathrm{NI}$ & 1 & \\
\hline Program13 & MI & LI & FI & $\mathrm{HI}$ & MI & LI & MI & MI & LI & FI & $\mathrm{HI}$ & LI & LI & MI & HI & LI & $\mathrm{HI}$ & NI & MI & MI & $\mathrm{NI}$ & LI & FI & NI & MI & $\mathrm{HI}$ & MI & $\mathrm{HI}$ & MI & HI & 2 & \\
\hline Program14 & $\mathrm{HI}$ & LI & NI & MI & LI & NI & LI & $\mathrm{HI}$ & FI & LI & MI & FI & MI & HI & FI & LI & FI & LI & MI & NI & MI & NI & LI & NI & LI & MI & LI & HI & NI & $\mathrm{HI}$ & 2 & \\
\hline Program15 & MI & MI & $\mathrm{HI}$ & FI & HI & MI & LI & FI & FI & MI & LI & NI & HI & HI & MI & LI & MI & MI & LI & FI & LI & MI & $\mathrm{HI}$ & FI & LI & MI & LI & NI & LI & FI & 2 & \\
\hline Program16 & LI & HI & LI & MI & MI & MI & LI & LI & FI & MI & LI & HI & FI & FI & LI & LI & HI & HI & HI & HI & $\mathrm{NI}$ & HI & FI & HI & NI & LI & NI & $\begin{array}{ll}\text { LI } \\
\end{array}$ & MI & LI & 2 & \\
\hline \begin{tabular}{|l|} 
Program17 \\
\end{tabular} & $\mathrm{FI}$ & MI & MI & $\mathrm{HI}$ & MI & $\mathrm{HI}$ & $\mathrm{HI}$ & FI & $\mathrm{HI}$ & FI & $\mathrm{NI}$ & $\mathrm{HI}$ & FI & FI & LI & $\mathrm{NI}$ & MI & FI & FI & MI & LI & MI & $\mathrm{HI}$ & $\mathrm{HI}$ & MI & LI & MI & NI & MI & LI & 3 & \\
\hline Program18 & MI & MI & MI & $\mathrm{NI}$ & LI & MI & NI & $\mathrm{NI}$ & MI & MI & NI & LI & FI & NI & MI & $\mathrm{HI}$ & MI & MI & LI & MI & FI & LI & LI & NI & NI & $\mathrm{HI}$ & NI & HI & $\mathrm{NI}$ & HI & 1 & \\
\hline \begin{tabular}{|l|} 
Program19 \\
\end{tabular} & MI & MI & $\mathrm{HI}$ & FI & $\mathrm{HI}$ & MI & LI & LI & $\mathrm{HI}$ & LI & MI & MI & MI & LI & $\mathrm{HI}$ & $\mathrm{HI}$ & MI & $\mathrm{HI}$ & FI & $\mathrm{HI}$ & MI & FI & MI & $\mathrm{HI}$ & FI & LI & FI & NI & MI & LI & 3 & \\
\hline Program20 & LI & $\mathrm{HI}$ & LI & MI & MI & MI & LI & LI & HI & LI & MI & MI & MI & LI & HI & FI & MI & FI & FI & MI & LI & NI & HI & HI & MI & LI & MI & NI & NI & NI & 2 & \\
\hline Program21 & $\mathrm{HI}$ & $\mathrm{HI}$ & LI & FI & HI & HI & HI & MI & MI & HI & MI & HI & HI & LI & FI & LI & HI & LI & FI & MI & LI & HI & FI & FI & LI & LI & HI & MI & LI & FI & 3 & \\
\hline Program22 & NI & MI & MI & NI & LI & FI & NI & HI & FI & LI & MI & FI & MI & HI & FI & LI & FI & FI & HI & FI & NI & HI & FI & FI & LI & NI & MI & LI & MI & NI & 2 & \\
\hline Program23 & NI & MI & MI & NI & LI & FI & NI & HI & HI & HI & NI & HI & FI & HI & NI & LI & NI & NI & MI & MI & $\mathrm{NI}$ & LI & FI & NI & MI & HI & MI & $\mathrm{HI}$ & MI & HI & 2 & \\
\hline Program24 & HI & FI & LI & LI & FI & MI & HI & FI & LI & MI & MI & MI & HI & HI & LI & MI & FI & $\mathrm{HI}$ & FI & LI & $\mathrm{HI}$ & FI & MI & HI & FI & LI & FI & MI & MI & LI & 3 & \\
\hline Program25 & FI & FI & MI & LI & MI & MI & $\mathrm{HI}$ & LI & FI & MI & LI & HI & FI & FI & LI & LI & HI & HI & HI & HI & $\mathrm{NI}$ & $\mathrm{HI}$ & FI & HI & NI & LI & NI & LI & MI & MI & 2 & \\
\hline Program26 & LI & MI & NI & $\mathrm{HI}$ & NI & LI & $\mathrm{HI}$ & FI & FI & MI & LI & NI & HI & HI & MI & LI & MI & NI & FI & MI & LI & $\mathrm{HI}$ & FI & FI & LI & LI & $\mathrm{HI}$ & FI & MI & $\mathrm{HI}$ & 2 & \\
\hline Program27 & LI & HI & LI & MI & MI & MI & LI & NI & FI & MI & LI & $\mathrm{HI}$ & FI & FI & LI & LI & LI & LI & HI & LI & MI & NI & MI & LI & HI & LI & MI & $\mathrm{HI}$ & FI & LI & 2 & \\
\hline Program28 & HI & MI & NI & MI & LI & NI & LI & LI & HI & LI & MI & MI & MI & LI & HI & LI & MI & NI & LI & NI & MI & LI & LI & LI & NI & NI & NI & MI & NI & MI & 1 & \\
\hline Program29 & MI & LI & FI & $\mathrm{HI}$ & MI & LI & MI & MI & LI & MI & FI & LI & LI & NI & $\mathrm{NI}$ & $\mathrm{HI}$ & $\mathrm{NI}$ & $\mathrm{HI}$ & $\mathrm{HI}$ & $\mathrm{HI}$ & $\mathrm{NI}$ & $\mathrm{HI}$ & $\mathrm{HI}$ & $\mathrm{HI}$ & $\mathrm{NI}$ & LI & NI & LI & $\mathrm{NI}$ & LI & 2 & 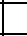 \\
\hline Program30 & NI & NI & LI & FI & LI & NI & NI & NI & LI & NI & MI & LI & MI & LI & NI & MI & NI & NI & LI & NI & MI & LI & MI & $\begin{array}{ll}\text { LI } \\
\end{array}$ & NI & HI & NI & NI & MI & NI & 1 & \\
\hline
\end{tabular}


Table 4: Objects Count in an Elementary set Based on Similar Attribute Values of Programs.

\begin{tabular}{|c|c|c|}
\hline Program & $\left|X_{i}^{D}\right|$ & $\left|X_{i}\right|$ \\
\hline Program01 & 7 & 4 \\
\hline Program02 & 7 & 2 \\
\hline Program03 & 7 & 4 \\
\hline Program04 & 7 & 2 \\
\hline Program05 & 16 & 3 \\
\hline Program06 & 16 & 6 \\
\hline Program07 & 16 & 6 \\
\hline Program08 & 7 & 4 \\
\hline Program09 & 16 & 4 \\
\hline Program10 & 7 & 2 \\
\hline Program11 & 16 & 3 \\
\hline Program12 & 7 & 2 \\
\hline Program13 & 16 & 4 \\
\hline Program14 & 16 & 3 \\
\hline Program15 & 16 & 4 \\
\hline Program16 & 16 & 6 \\
\hline Program17 & 7 & 4 \\
\hline Program18 & 7 & 2 \\
\hline Program19 & 7 & 1 \\
\hline Program20 & 16 & 6 \\
\hline Program21 & 7 & 2 \\
\hline Program22 & 16 & 2 \\
\hline Program23 & 16 & 2 \\
\hline Program24 & 7 & 2 \\
\hline Program25 & 16 & 1 \\
\hline Program26 & 16 & 6 \\
\hline Program27 & 16 & \\
\hline Program28 & 7 & 16 \\
\hline Program29 & 7 & 4 \\
\hline Program30 & & 4 \\
\hline & 76 & 4 \\
\hline
\end{tabular}


Table 5: The Weight and Information Significance of GSCM practices.

\begin{tabular}{|c|c|c|}
\hline $\begin{array}{c}\text { GSCM } \\
\text { practices }\end{array}$ & $\begin{array}{c}\text { Information } \\
\text { Significance }\end{array}$ & Weight \\
\hline GITS1 & 0.282 & 0.0346 \\
\hline GITS2 & 0.282 & 0.0346 \\
\hline GITS3 & 0.284 & 0.0349 \\
\hline GITS4 & 0.304 & 0.0373 \\
\hline GITS5 & 0.271 & 0.0333 \\
\hline SSP1 & 0.262 & 0.0322 \\
\hline SSP2 & 0.282 & 0.0346 \\
\hline SSP3 & 0.297 & 0.0365 \\
\hline SSP4 & 0.264 & 0.0324 \\
\hline SSP5 & 0.284 & 0.0349 \\
\hline SSP6 & 0.249 & 0.0306 \\
\hline OLI1 & 0.291 & 0.0357 \\
\hline OLI2 & 0.289 & 0.0355 \\
\hline OLI3 & 0.275 & 0.0338 \\
\hline OLI4 & 0.304 & 0.0373 \\
\hline IEM1 & 0.217 & 0.0266 \\
\hline IEM2 & 0.293 & 0.036 \\
\hline IEM3 & 0.275 & 0.0338 \\
\hline IEM4 & 0.246 & 0.0302 \\
\hline IEM5 & 0.273 & 0.0335 \\
\hline IEM6 & 0.249 & 0.0306 \\
\hline ECO1 & 0.251 & 0.0308 \\
\hline ECO2 & 0.253 & 0.0311 \\
\hline ECO3 & 0.251 & 0.0308 \\
\hline ECO4 & 0.269 & 0.033 \\
\hline EOL1 & 0.249 & 0.0306 \\
\hline EOL2 & 0.275 & 0.0338 \\
\hline EOL3 & 0.289 & 0.0355 \\
\hline EOL4 & 0.257 & 0.0316 \\
\hline EOL5 & 0.277 & 0.034 \\
\hline & & \\
\hline & & 0.96 \\
\hline
\end{tabular}

Table 6 . The linguistic variables and their corresponding triangle fuzzy numbers.

\begin{tabular}{|c|c|}
\hline linguistic variables & triangular fuzzy numbers $\tilde{v}$ \\
\hline No Involvement (NI) & $\left(\begin{array}{lll}0, & 0.1, & 0.3)\end{array}\right.$ \\
\hline Low Involvement (LI) & $(0.1,0.3,0.5)$ \\
\hline Moderate Involvement (MI) & $\left(\begin{array}{lll}0.3, & 0.5, & 0.7)\end{array}\right.$ \\
\hline High Involvement (HI) & $\left(\begin{array}{lll}0.5, & 0.7, & 0.9)\end{array}\right.$ \\
\hline Full Involvement (FI) & $(0.7,0.9,1.0)$ \\
\hline
\end{tabular}


Table 7: Combined Weight Scores of GSCM Program on Practices

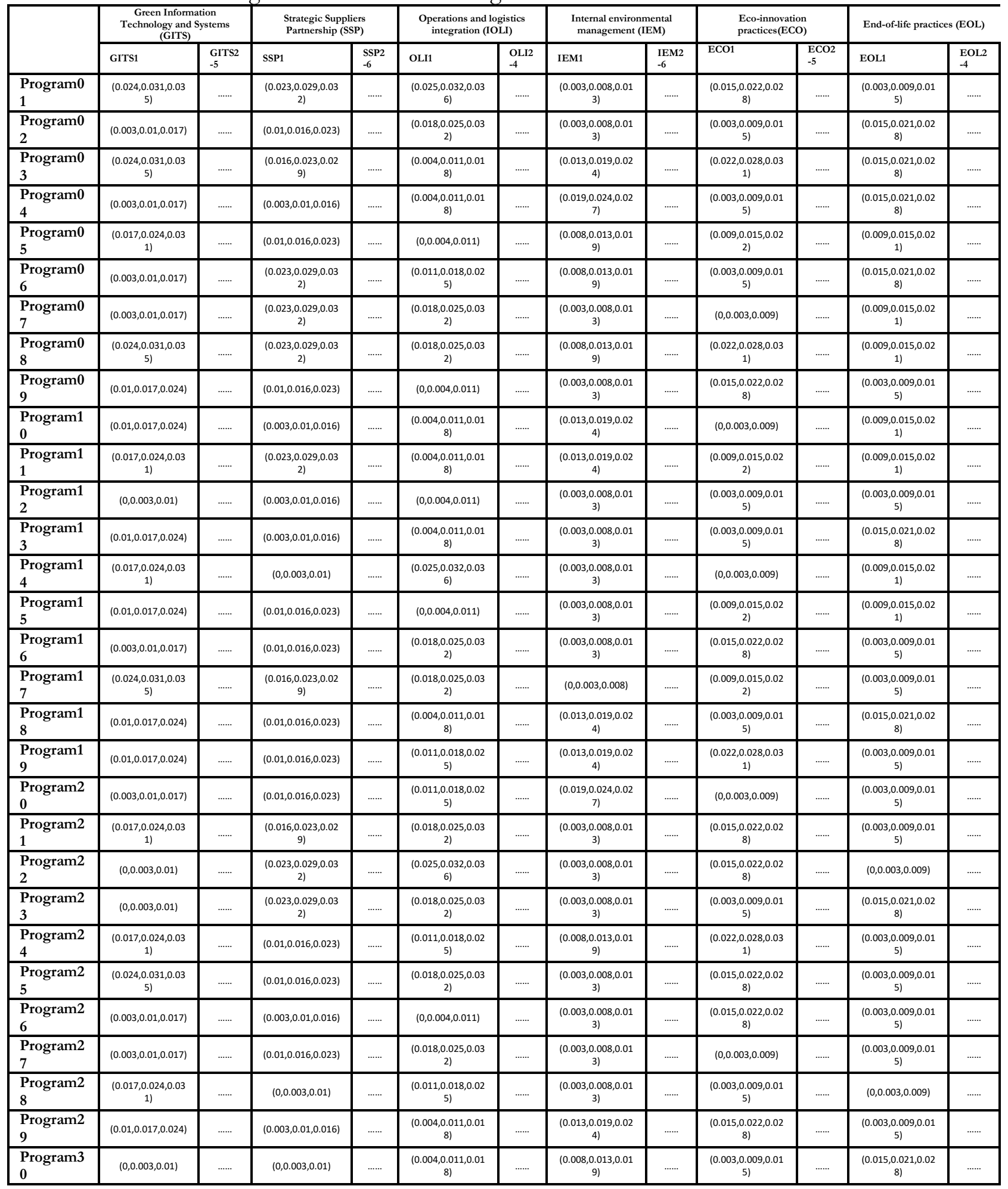


Table 8: The Relative Closeness of GSCM Program

\begin{tabular}{|c|c|c|c|c|c|c|c|c|}
\hline & \multicolumn{4}{|c|}{ Environmentally Oriented Performance(d1) } & \multicolumn{2}{|c|}{$\begin{array}{l}\text { BusinessOriented } \\
\text { Performance(d2) }\end{array}$} & \multicolumn{2}{|c|}{$\begin{array}{c}\text { Environmentally } \\
\text { Oriented } \\
\text { Performance(d1) with no } \\
\text { weight }\end{array}$} \\
\hline & $\mu_{i}^{+}$ & $\mu_{i}^{-}$ & $T_{i}$ & Ranking & $T_{i}$ & Ranking & $T_{i}$ & Ranking \\
\hline Program01 & 0.247 & 0.48 & 0.661 & 3 & 0.654 & 3 & 0.654 & 3 \\
\hline Program02 & 0.455 & 0.272 & 0.374 & 24 & 0.371 & 25 & 0.369 & 25 \\
\hline Program03 & 0.235 & 0.492 & 0.677 & 2 & 0.68 & 2 & 0.679 & 2 \\
\hline Program04 & 0.457 & 0.269 & 0.37 & 25 & 0.375 & 24 & 0.375 & 24 \\
\hline Program05 & 0.402 & 0.325 & 0.447 & 19 & 0.446 & 21 & 0.45 & 20 \\
\hline Program06 & 0.329 & 0.398 & 0.548 & 10 & 0.544 & 11 & 0.545 & 10 \\
\hline Program07 & 0.37 & 0.356 & 0.49 & 17 & 0.484 & 17 & 0.486 & 17 \\
\hline Program08 & 0.201 & 0.525 & 0.723 & 1 & 0.729 & 1 & 0.724 & 1 \\
\hline Program09 & 0.306 & 0.421 & 0.579 & 7 & 0.58 & 8 & 0.573 & 8 \\
\hline Program10 & 0.48 & 0.247 & 0.34 & 27 & 0.344 & 27 & 0.345 & 27 \\
\hline Program11 & 0.35 & 0.376 & 0.518 & 14 & 0.52 & 14 & 0.522 & 14 \\
\hline Program12 & 0.537 & 0.191 & 0.262 & 29 & 0.268 & 29 & 0.268 & 29 \\
\hline Program13 & 0.362 & 0.366 & 0.502 & 15 & 0.499 & 16 & 0.496 & 15 \\
\hline Program14 & 0.412 & 0.315 & 0.434 & 22 & 0.428 & 22 & 0.426 & 22 \\
\hline Program15 & 0.334 & 0.393 & 0.541 & 11 & 0.538 & 12 & 0.536 & 12 \\
\hline Program16 & 0.369 & 0.359 & 0.493 & 16 & 0.5 & 15 & 0.495 & 16 \\
\hline Program17 & 0.292 & 0.435 & 0.599 & 6 & 0.595 & 6 & 0.591 & 6 \\
\hline Program18 & 0.46 & 0.266 & 0.366 & 26 & 0.367 & 26 & 0.368 & 26 \\
\hline Program19 & 0.308 & 0.419 & 0.576 & 8 & 0.586 & 7 & 0.582 & 7 \\
\hline Program20 & 0.403 & 0.325 & 0.446 & 20 & 0.454 & 19 & 0.452 & 19 \\
\hline Program21 & 0.27 & 0.458 & 0.63 & 4 & 0.63 & 5 & 0.625 & 5 \\
\hline Program22 & 0.336 & 0.39 & 0.538 & 12 & 0.545 & 10 & 0.538 & 11 \\
\hline Program23 & 0.406 & 0.32 & 0.44 & 21 & 0.447 & 20 & 0.44 & 21 \\
\hline Program24 & 0.269 & 0.458 & 0.63 & 5 & 0.632 & 4 & 0.632 & 4 \\
\hline Program25 & 0.322 & 0.405 & 0.557 & 9 & 0.556 & 9 & 0.556 & 9 \\
\hline Program26 & 0.341 & 0.387 & 0.532 & 13 & 0.538 & 13 & 0.53 & 13 \\
\hline Program27 & 0.389 & 0.339 & 0.466 & 18 & 0.471 & 18 & 0.466 & 18 \\
\hline Program28 & 0.509 & 0.218 & 0.3 & 28 & 0.297 & 28 & 0.296 & 28 \\
\hline Program29 & 0.433 & 0.295 & 0.405 & 23 & 0.411 & 23 & 0.411 & 23 \\
\hline Program30 & 0.577 & 0.148 & 0.204 & 30 & 0.211 & 30 & 0.211 & 30 \\
\hline
\end{tabular}

